\title{
Silage review: Animal and human health risks from silage ${ }^{1}$
}

\author{
F. Driehuis, ${ }^{* 2}$ J. M. Wilkinson, $†$ Y. Jiang, $\ddagger$ I. Ogunade, $\ddagger$ and A. T. Adesogan $\ddagger$ \\ ${ }^{*}$ NIZO Food Research, PO Box 20, NL-6710 BA Ede, the Netherlands \\ †School of Biosciences, University of Nottingham, Sutton Bonington Campus, Loughborough, Leicestershire, LE12 5RD, United Kingdom \\ ‡Department of Animal Sciences, Institute of Food and Agricultural Sciences, University of Florida, Gainesville 32608
}

\section{ABSTRACT}

Silage may contain several agents that are potentially hazardous to animal health, the safety of milk or other animal food products, or both. This paper reviews published literature about microbial hazards, plant toxins, and chemical hazards. Microbial hazards include Clostridium botulinum, Bacillus cereus, Listeria monocytogenes, Shiga toxin-producing Escherichia coli, Mycobacterium bovis, and various mold species. High concentrations of $C$. botulinum in silage have been associated with cattle botulism. A high initial concentration of $C$. botulinum spores in forage in combination with poor silage fermentation conditions can promote the growth of $C$. botulinum in silage. The elevated $\mathrm{pH}$ level that is generally associated with aerobic deterioration of silage is a major factor influencing concentrations of L. monocytogenes, Shiga toxin-producing E. coli, and molds in silage and may also encourage survival and growth of $M$. bovis, the bacterium that causes bovine tuberculosis. Soil is a major source of $B$. cereus spores in silage; growth of this bacterium in silage appears to be limited. Hazards from plant toxins include pyrrolizidine, tropane and tropolone alkaloids, phytoestrogens, prussic acid, and mimosine, compounds that exist naturally in certain plant species that may contaminate forages at harvesting. Another group of toxins belonging to this category are ergot alkaloids, which are produced by endophytic fungal species in forages such as tall fescue grass, sorghum, and ryegrass. Varying effects of ensiling on the degradation of these plant toxins have been reported. Chemical hazards include nitrate, nitrite, and toxic oxide gases of nitrogen produced from nitrate and high levels of butyric acid, biogenic amines, and ammonia. Chemical and microbiological hazards are associated with poorly fermented silages, which can be avoided by using proper silage-making practices and creating conditions that promote a rapid and sufficient

Received September 14, 2017.

Accepted November 16, 2017.

${ }^{1}$ This article is part of a special issue on silage management.

${ }^{2}$ Corresponding author: Frank.Driehuis@nizo.com reduction of the silage $\mathrm{pH}$ and prevent aerobic deterioration.

Key words: silage quality, pathogens, toxins, chemical hazards

\section{INTRODUCTION}

The production of well-preserved, high-quality silages depends mainly on the composition of the forage at ensiling and the application of appropriate silage-making practices. The main principles of silage preservation are a rapid achievement of a low $\mathrm{pH}$ by lactic acid fermentation and the maintenance of anoxic conditions (Pahlow et al., 2003). Lactic acid bacteria play a key role in ensuring the success of the ensiling process. They are capable of converting fermentable carbohydrates that are present in forage crops at a high rate to lactic acid and, to a lesser extent, acetic acid. Chemical and biological silage additives can assist in making well-preserved silages by promoting a rapid reduction in silage $\mathrm{pH}$ and preventing aerobic deterioration (Kung et al., 2003; Muck et al., 2018). Properly made and managed silage is an excellent feed that poses no health risks to humans or livestock. In fact, the microbes in such silages may have probiotic effects on livestock (Weinberg et al., 2003). However, different undesirable microorganisms may develop in silage when the $\mathrm{pH}$ is insufficiently reduced or when oxygen is available. These undesirable microorganisms include both those that are detrimental for the nutritional quality of silage, for instance yeasts and butyric acid bacteria, and those that can be hazardous to animal health or the safety of milk or other animal food products, such as Clostridium botulinum, Bacillus cereus, Listeria monocytogenes, Escherichia coli, other Enterobacteriaceae species, and molds. The health hazard can be the microorganism itself or a metabolite that is produced, such as mycotoxins produced by certain molds. In addition to microbial health hazards, silages may contain toxic chemical substances resulting from ensiling of the forage crop or from various contaminants.

In this paper, 3 types of health hazards associated with silage are described. First, hazards associated 
with the growth and metabolism of undesirable microorganisms during ensiling, including C. botulinum, $B$. cereus, L. monocytogenes, Shiga toxin-producing E. coli, and molds. Second, toxins present in plant tissues at harvest that may survive the ensiling process. Finally, chemical hazards associated with undesirable silage fermentations, including nitrogenous gases, high butyric acid levels, and biogenic amines.

\section{MICROBIAL HAZARDS}

\section{Clostridium botulinum}

Clostridium species are gram-positive, obligate anaerobic spore-forming bacteria. Clostridia require relative high $\mathrm{pH}$ values $(>4.5)$, high forage moisture concentration $(>70 \%)$, and high water activity (from 0.952 to 0.971 ) for growth; hence, they are inhibited in silages if rapid acidification reduces the $\mathrm{pH}$ to 4 or below within 3 d (Muck et al., 2003). The critical pH that inhibits clostridial growth varies with the plant moisture content (Figure 1). Therefore, factors that predispose the plant to high moisture concentrations at harvest or ensiling or that delay the $\mathrm{pH}$ decline during ensiling can favor clostridial growth. The buffering capacity of the ensiled crop is an important factor in the development of clostridia, as the higher the buffering capacity the more lactic acid must be produced to achieve the critical $\mathrm{pH}$ to inhibit clostridial growth. Hazards associated with production of butyric acid by clostridia are discussed under the butyric acid subsection in the chemical hazard section below.

Non-pathogenic Clostridium species that commonly occur in silage include C. tyrobutyricum, C. beijerinckii,

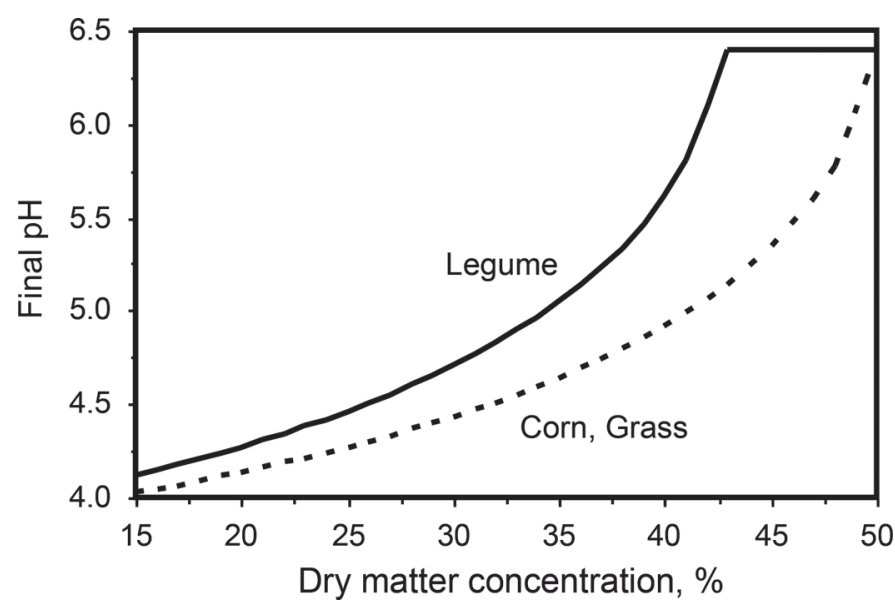

Figure 1. The $\mathrm{pH}$ below which growth of Clostridium tyrobutyricum ceases. Adapted based on equations of Leibensperger and Pitt (1987).
C. butyricum, and C. sporogenes (Pahlow et al., 2003; Driehuis, 2013; Doyle et al., 2015). Pathogenic Clostridium species include $C$. perfringens, $C$. difficile, $C$. tetani, and C. botulinum (Doyle et al., 2015). Of these pathogenic species, only C. botulinum is occasionally associated with silage.

The species $C$. botulinum is a heterogeneous group of bacteria that has the ability to produce the neurotoxin botulinum, the agent that causes botulism. Botulinum is a protein toxin and is believed to be the most potent toxin in nature (Schantz and Johnson, 1992). Four discrete groups of $C$. botulinum bacteria exist (Table 1; Collins and East, 1998; Carter and Peck, 2015). Clostridium botulinum Groups I and II are primarily responsible for human botulism; C. botulinum Group III is responsible for botulism in various animal species, primarily birds and cattle; and C. botulinum Group IV does not appear to be associated with botulism in humans or animals (Carter and Peck, 2015). Seven different types of botulinum toxins are recognized, designated types A to G (Collins and East, 1998; Carter and Peck, 2015). Botulinum types C and D and occasionally type B are associated with botulism in animals, whereas botulism in humans is associated with the remaining botulinum types and type B. The different C. botulinum groups also differ significantly with respect to their phenotypic properties, such as minimum and optimal growth temperatures, proteolytic activity, carbohydrate metabolism, and the heat resistance of spores (Table 1 ).

Botulism is a severe disease in both humans and animals; the fatality rate is high, at approximately 5 to $10 \%$ of cases in humans and generally higher than $10 \%$ in cattle (Galey et al., 2000; Sobel et al., 2004; Payne et al., 2011). Botulism in cattle is an intoxication caused by ingestion of feed (or water) contaminated with botulinum toxin. Table 2 gives an overview of published cases of feed-associated botulism in cattle, including the identified botulinum toxin type and the confirmed or presumed source of $C$. botulinum spores or toxin. Contaminated silages were involved in many of these cases. In an outbreak of cattle botulism affecting multiple farms in the Netherlands, $C$. botulinum type $\mathrm{B}$ and botulinum toxin type $\mathrm{B}$ were detected in ensiled brewers' grains and grass silage at one of these farms (Haagsma and Ter Laak, 1978a,b; Notermans et al., 1981). Spores of C. botulinum type B were detected in cow feces and manure from cattle that was fed the contaminated ensiled brewers' grains and which had been spread over grass pastures for fertilization (Notermans et al., 1981). The 2 following years, spores of C. botulinum type B were detected in 5 grass silages produced from these pastures and botulinum toxin type 
Table 1. Characteristics of Clostridium botulinum Group I, II, III, and IV (Collins and East, 1998; Carter and Peck, 2015)

\begin{tabular}{|c|c|c|c|c|}
\hline Item & \multicolumn{4}{|c|}{ Group } \\
\hline $\begin{array}{l}\text { Botulinum toxin type } \\
\text { Associated with botulism in } \\
\text { Proteolysis } \\
\text { Optimum growth temperature } \\
\text { Minimum growth temperature } \\
\text { Spore heat resistance }^{2}\end{array}$ & $\begin{array}{l}\mathrm{A}, \mathrm{B}, \mathrm{F}, \mathrm{H}^{1} \\
\text { Humans } \\
+ \\
37^{\circ} \mathrm{C} \\
12^{\circ} \mathrm{C} \\
\mathrm{D}_{121^{\circ} \mathrm{C}}=0.21 \mathrm{~min}\end{array}$ & $\begin{array}{l}\mathrm{B}, \mathrm{E}, \mathrm{F} \\
\text { Humans } \\
- \\
30^{\circ} \mathrm{C} \\
3^{\circ} \mathrm{C} \\
\mathrm{D}_{82.2^{\circ} \mathrm{C}}=2.4 \mathrm{~min}\end{array}$ & $\begin{array}{l}\mathrm{C}, \mathrm{D} \\
\text { Animals } \\
- \\
40^{\circ} \mathrm{C} \\
15^{\circ} \mathrm{C} \\
\mathrm{D}_{104^{\circ} \mathrm{C}}=0.1-0.9 \mathrm{~min}\end{array}$ & $\begin{array}{l}\mathrm{G} \\
+ \\
37^{\circ} \mathrm{C} \\
\mathrm{D}_{104^{\circ} \mathrm{C}}=0.8-1.1 \mathrm{~min}\end{array}$ \\
\hline
\end{tabular}

${ }^{1}$ More than 1 toxin type may be formed.

${ }^{2} \mathrm{D}$-value (decimal reduction time) at specified temperature (i.e., time to a 10 -fold reduction in viable spores).

B was detected in 4 samples from 2 of these silages. During these investigations, no clinical symptoms of cattle botulism were observed at the farms where the silages were produced. Presence of $C$. botulinum spores and botulinum toxin in grass silage in these studies was associated with high $\mathrm{pH}$ ( $\mathrm{pH}$ between 5.3 and 6.4), indicating poor silage preservation (Notermans et al., 1981). A poor correlation between spore concentration and the presence of toxin was found by Notermans et al. (1981). This may be explained by the fact that toxin is produced by vegetative $C$. botulinum, which are not enumerated in the determination of spores of $C$. botulinum. Kelch et al. (2000) reported on an outbreak of cattle botulism in a herd of cattle in Tennessee that was caused by the feeding of bales of barley silage. Those authors detected $C$. botulinum type B spores in samples of samples of 3 bales of barley silage and detected $C$. botulinum type $\mathrm{B}$ toxin in 1 of these samples. To our knowledge, studies that investigated the conditions that promote spore germination, growth, and toxin production by $C$. botulinum in silage are lacking.

A case of cattle botulism in Finland was linked to the feeding of poorly preserved grass silage that was contaminated by pieces of animal carcass material, presumed to originate from poultry carcass material in pastures of the farm (Myllykoski et al., 2009). In a similar case in Austria was linked to grass silage produced from a pasture on which cow manure was spread that was contaminated by cat carcass material (Kummel et al., 2012). However, these latter 2 studies did not provide evidence for the occurrence of $C$. botulinum spores or toxins in the silages.

Spores of $C$. botulinum are widely distributed in soil and occur, generally in low numbers, in feed crops and in the intestinal tract of animals, including cattle (EFSA, 2005). Generally, exposure to low numbers of C. botulinum or spores of this microorganism is not harmful. However, any factors that induce multiplication of $C$. botulinum must be avoided because of the extreme toxicity of the botulinum toxin. As with spores of other spore-forming bacteria occurring in the intes- tinal tract of cows, spores of $C$. botulinum are shed in the feces of infected animals (Notermans et al., 1981). Data about the concentration of $C$. botulinum spores in raw milk are scarce. Based on studies in Canada, the concentration of $C$. botulinum spores in raw milk of unaffected cows is estimated to be about 1 spore per liter (Collins-Thompson and Woods, 1992). Milk and dairy products are seldom implicated in incidences of food-borne botulism, which rarely occur. Although C. botulinum spores are not inactivated by the milk pasteurization processes commonly used in the dairy industry $\left(72-75^{\circ} \mathrm{C}\right.$ for $\left.15 \mathrm{~s}\right)$, multiplication of $C$. botulinum is generally uncommon in products made from pasteurized milk (refrigerated). For nonrefrigerated commercially sterile products, heat treatment processes and product formulations are designed to secure a minimum of $12-\log$ reduction of $C$. botulinum spores or prevent any multiplication (Anderson et al., 2011). The rare cases of food-borne botulism associated with dairy products since 1912 were reviewed by Lindström et al. (2010). Dairy products that are used in infant formula, such as milk powder and dried whey products, require special attention with respect to the occurrence of $C$. botulinum spores because of the potential risk of the spores causing infant botulism. Dried infant formula powder containing $C$. botulinum spores in a concentration of about 1 to 4 spores $/ \mathrm{kg}$ was traced as the source of an infant botulism case in the United Kingdom in 2001 (Brett et al., 2005).

Transmission of $C$. botulinum spores to milk can occur during milking operations, and the transmission pathway is the same as that for spores of butyric acid bacteria and other spore formers from silage (Driehuis, 2013). Under normal farming and animal housing practices, it is inevitable that the skin of the cow's udder and teats becomes soiled with bacteria and spores from feces and other sources, including bedding. Although good dairy farming practice requires that teats are cleaned before milking (FAO and IDF, 2011), teatcleaning methods are relatively inefficient from a microbiological perspective (Magnusson et al., 2006). As 


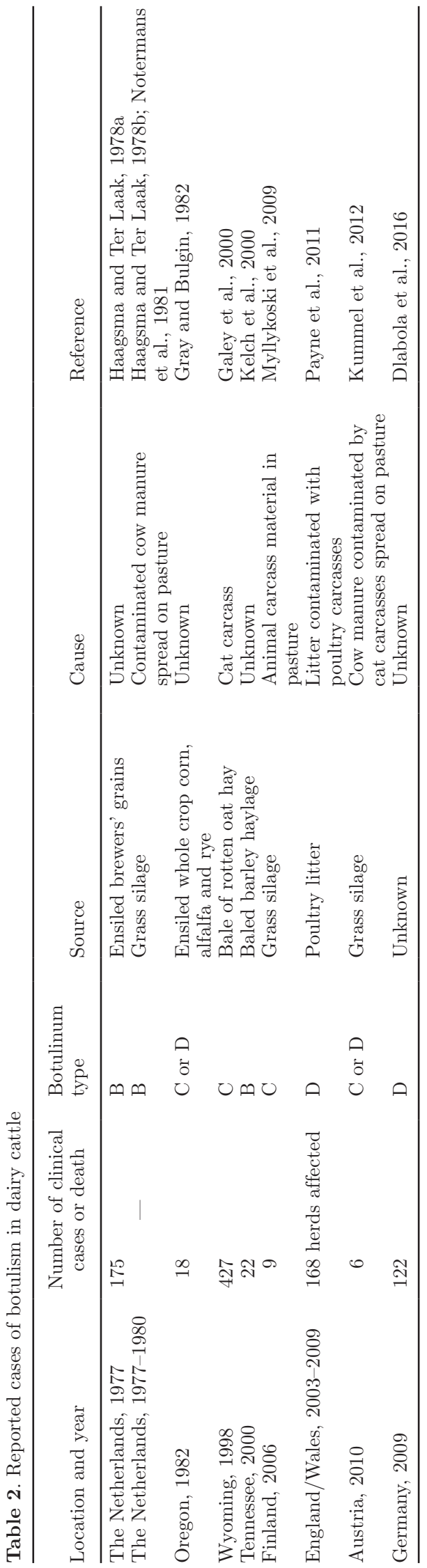

a result, a significant fraction of the bacteria and spores from feces that are attached to the teats skin surface are not removed by teat-cleaning with a portion being rinsed off during the milking operation (Magnusson et al., 2006; Vissers et al., 2007a).

\section{Bacillus cereus}

Bacilli and paenibacilli are aerobic or facultatively anaerobic spore-forming bacteria. Species typically associated with silage include Bacillus licheniformis, $B a$ cillus pumilus, Bacillus coagulans, Bacillus sphaericus, Bacillus cereus, and Paenibacillus polymyxa (formerly Bacillus polymyxa; Driehuis, 2013). Bacillus cereus is of particular concern because it is a food-borne pathogen in humans.

There are different sources of spores of B. cereus in milk, including soil, silage and other feeds and bedding materials. Soil is a major source of spores of $B$. cereus and other spore-formers. Concentrations in soil of spores of aerobic spore-formers vary from $10^{5}$ to $10^{7}$ spores $/ \mathrm{g}$, and spores of B. cereus vary from $10^{1}$ to $10^{6}$ spores/g depending on soil type, sampling site, and season (Driehuis, 2013). In studies conducted in Sweden, soil was identified as the major source of contamination of raw milk by $B$. cereus spores during grazing of cows, whereas sawdust bedding was a major source when cows were kept indoors (Christiansson et al., 1999; Magnusson et al., 2007). Occurrence of B. cereus spores in silage is inevitable due to the contamination of silage by soil. The average concentration of $B$. cereus spores detected in mixed grass and corn silage fed to dairy cattle at farms in the Netherlands was about $3 \times 10^{2}$ spores/g (Vissers et al., 2007b). In their study, silage was identified as the major source of $B$. cereus spores in raw milk. High concentrations of spores $\left(10^{8}\right.$ to $10^{9}$ spores/g) from aerobic spore-formers have been detected in surface layers and moldy areas of silages (Pahlow et al., 2003), causing aerobic deterioration. However, $B$. cereus does not increase in numbers to the same extent as other members of the group of aerobic spore-formers. The maximum concentration of $B$. cereus spores detected in silage samples in the Netherlands was about $10^{4}$ spores/g (Vissers et al., 2007b). It remains to be seen whether significant growth of $B$. cereus can occur in silages. No growth of $B$. cereus in well-acidified silage is expected, as growth of the bacterium is inhibited at pH below 4.6 (Browne and Dowds, 2002; Biesta-Peters et al., 2010). However, growth of B. cereus in areas of silage where aerobic deterioration has caused the $\mathrm{pH}$ to increase to above 4.6 may be theoretically be possible.

Bacillus cereus spores occurring in silage and other feeds pass the gastrointestinal tract of cattle unaffected and are shed in the feces. As described previously for $C$. 
botulinum, spores of $B$. cereus can be transferred to raw milk during milking operations due to soiling of teat surfaces with feces. Grass and whole-crop maize silages and other feed types have been identified as important sources of $B$. cereus spores in raw milk in studies in the Netherlands (Vissers et al., 2007b). In contrast, soil and sawdust bedding were identified as the major sources of contamination of raw milk by $B$. cereus in studies conducted in Sweden (Christiansson et al., 1999; Magnusson et al., 2007).

Bacillus cereus is a major spoilage organism of pasteurized milk and milk products stored at refrigeration temperature (Griffiths, 1992; Te Giffel, 1997; Heyndrickx and Scheldeman, 2002). Spores of psychrotrophic B. cereus strains are capable of germination and the bacterium can grow in pasteurized milk and milk products at temperatures as low as $5^{\circ} \mathrm{C}$. The concentration of spores of psychrotrophic B. cereus often limits the shelf life of these products, as high levels may cause off-flavors and curdling. Bacillus cereus spores also occur in powdered dairy products. For example, 1.3, 17.2, and $13.3 \%$ of the spores of aerobic spore-formers isolated from nonfat milk powder, sweet whey powder, and whey protein concentrate (WPC-80), respectively, were identified as B. cereus (Miller et al., 2015). Despite the frequent contamination, B. cereus is rarely implicated in outbreaks of food-borne illness associated with dairy products (Bennett et al., 2013). This may be associated with the atypical appearance or smell of products with a high level of $B$. cereus, which reduces the chance that those products will be consumed.

\section{Listeria monocytogenes}

Listeria monocytogenes is a pathogen that causes severe systemic infections (listeriosis) in humans and animals, including cattle, sheep, and goats. Due to the severity of this disease, the high mortality rate, and the increasing incidence, L. monocytogenes is of great concern to public health (EFSA and ECDC, 2016).

Listeriosis in humans caused by L. monocytogenes occurs in 2 forms, as a noninvasive gastrointestinal illness or as an invasive disease. The noninvasive gastrointestinal form occurs in otherwise healthy adults and is a relatively mild disease with symptoms that are typical of gastroenteritis (fever, diarrhea, and vomiting). Invasive listeriosis is a severe disease and most often occurs in adults with underlying immunosuppression (i.e., the elderly, pregnant women, and immune-compromised patients) and in neonates. Although invasive listeriosis outbreaks and sporadic cases are rare, the effect of these outbreaks is very significant, with case-fatality rates as high as 20 to $30 \%$ (Lomonaco et al., 2015). Lis- teria monocytogenes is therefore among the food-borne pathogens causing most deaths in developed countries annually (Scallan et al., 2011).

Listeriosis is often considered a food-borne disease of ruminants, with silage being the main feed source. In these animals, L. monocytogenes primarily causes encephalitis and uterine infections, the latter causing late-term abortions. In addition, L. monocytogenes can cause eye infections in ruminants (silage eye) as a result of direct contact with silage (Erdogan, 2010).

Listeria monocytogenes is a facultatively anaerobic gram-positive bacterium that is widely distributed in the environment. It has been isolated from a variety of sources, including soil, surface water, vegetative materials, and animal and human feces. Important features of $L$. monocytogenes are that it can grow over a wide range of temperatures $\left(0-45^{\circ} \mathrm{C}\right)$, salt concentrations (up to $12 \%$ ), and $\mathrm{pH}$ (4.3-9.6; Van der Veen et al., 2008; Gandhi and Chikindas, 2007). Due to its high tolerance to stressful conditions, L. monocytogenes is capable of survival for extended periods in environments in which it is unable to grow, for instance well-preserved silage. Survival of L. monocytogenes in silage is determined to a great extent by the degree of anaerobiosis and the $\mathrm{pH}$. Donald et al. (1995) showed that the population of L. monocytogenes rapidly declined under strictly anaerobic conditions when it was added to grass at ensiling, whereas oxygen tensions of $0.5 \%$ ( $\mathrm{vol} / \mathrm{vol}$ ) and higher prolonged survival. Therefore, poor compaction before ensiling or air ingress during the fermentation can promote the growth or persistence of this pathogen. Growth of L. monocytogenes in silage is also associated with aerobic deterioration problems. The combination of the presence of oxygen and relatively high $\mathrm{pH}$ in aerobically deteriorated silage favor growth of L. monocytogenes. Silages with a greater likelihood of aerobic surface spoilage, for example silage with a low packing density or inadequate sealing and baled silages, are most susceptible to contamination by L. monocytogenes (Fenlon et al., 1989). Studies by Ryser et al. (1997) and Vilar et al. (2007) have shown that the incidence of $L$. monocytogenes in silage increases with increasing $\mathrm{pH}$. Listeria monocytogenes was detected in concentrations in excess of $10^{6} \mathrm{cfu} / \mathrm{g}$ in moldy surface layers of big bale grass silages (Fenlon, 1986).

A causal relationship has been shown between feeding poor-quality silage and the prevalence of listeriosis in cattle, sheep, and goats (Fenlon, 1988; Wiedmann et al., 1997; Ho et al., 2007). Listeria monocytogenes from silage survives passage through the animal's gastrointestinal tract and is shed in the feces. This has not only been observed for cattle, sheep, and goats with clinical signs of listeriosis but also for asymptomatic carriers of 
L. monocytogenes on farms with and without outbreaks (Unnerstad et al., 2000; Nightingale et al., 2004; Vilar et al., 2007).

Contamination of raw cow milk by $L$. monocytogenes has been linked to the occurrence of high levels of $L$. monocytogenes in silage (Sanaa et al., 1993; , Tasci et al., 2010). Transmission of L. monocytogenes to milk most likely occurs during milking operations through the same transmission pathway as previously described for spores of $C$. botulinum and B. cereus. Another potential transmission route to milk is the shedding of $L$. monocytogenes by cows with mastitis caused by this bacterium (Bourry et al., 1995), although the incidence is low (Fedio et al., 1990).

Listeria monocytogenes occurs at low numbers in raw cow milk. Surveys of the prevalence of L. monocytogenes in bulk tank milk from dairy farms in the United States, New Zealand, France, and Belgium showed that 2.9 to $6.3 \%$ of the samples were positive (tested for presence in samples of $25 \mathrm{~g}$; Desmasures et al., 1997; de Reu et al., 2004; Van Kessel et al., 2011; Marshall et al., 2016). Listeria monocytogenes is sensitive to heat inactivation and is effectively inactivated by the pasteurization of milk.

The exposure of humans to low numbers of L. monocytogenes via foods is generally not considered a serious health risk. As L. monocytogenes is ubiquitous in the environment and many unprocessed foods, humans are commonly exposed to low numbers of this bacterium. For foods that are unable to support the growth of L. monocytogenes and those in which limited growth can occur, a maximum concentration of $100 \mathrm{cfu} / \mathrm{g}$ is a commonly applied food safety criterion (European Commission 2005). However, for foods that support the growth of L. monocytogenes, for instance raw and smoked fish, raw and cooked meat, and soft and semisoft cheeses produced from unpasteurized milk, a more strict food safety criterion is generally applied. For instance, European Union regulation 1441/2007 stipulates that for products that can support the growth of $L$. monocytogenes, the bacterium should be absent in five 25-g samples after production and that counts of the bacterium in the products should not exceed $100 \mathrm{cfu} / \mathrm{g}$ at the time of consumption (European Commission, 2007). Codex Alimentarius also specifies an absence of the pathogen in five 25 -g samples (World Health Organization and FAO, 2009).

\section{Shiga Toxin-Producing Escherichia coli}

Shiga toxin-producing E. coli (STEC) are an important cause of food-borne disease. The outcomes of STEC infection range from mild intestinal discomfort to severe diseases, such as hemorrhagic colitis, hemolytic uremic syndrome, and end-stage renal disease (Majowicz et al., 2014).

Escherichia coli is a facultatively anaerobic gramnegative bacterium belonging to Enterobacteriaceae. Most E. coli strains are nonpathogenic and part of the normal intestinal microbiota of humans and many animals. They also belong to the epiphytic microflora of forage crops. The majority of cases of STEC infection in humans have been associated with serotype O157:H7, but STEC serogroups O26, O103, O111, and O145 are also significant causes of human diseases (Gould et al., 2013).

Cattle are considered the main natural reservoir of STEC. Although they shed the pathogen in their feces, STEC do not cause disease in cattle. It has been determined that approximately 10 to $30 \%$ of cattle in Europe and the United States are carriers of STEC (Rogerie et al., 2001; Callaway et al., 2006).

We know of no studies to have shown the presence of STEC in well-made silage, except for one study in which E. coli $\mathrm{O} 157: \mathrm{H} 7$ was detected in fresh alfalfa forage before ensiling and in silage produced from this forage up to $16 \mathrm{~d}$ after ensiling (Ogunade et al., 2016). The persistence of the bacterium in the silage was probably due to the high buffering capacity of the crop, which reduced the rate of $\mathrm{pH}$ decrease such that the $\mathrm{pH}$ was still above 5 after $16 \mathrm{~d}$ of ensiling. Several studies investigated the survival and growth of STEC (E. coli O157:H7 and O26) in grass, corn, alfalfa, and barley inoculated with the pathogen before ensiling (Byrne et al., 2002; Bach et al., 2002; Pedroso et al., 2010; Dunière et al., 2011; Ogunade et al., 2016, 2017). These studies consistently showed that the STEC strains did not survive in well-fermented silage that exhibited a fast $\mathrm{pH}$ decline and low terminal $\mathrm{pH}$. However, Fenlon and Wilson (2000) showed that E. coli O157:H7 survived and increased in number in silage that was poorly fermented due to air infiltration. Chen et al. (2005) showed that an inoculated E. coli strain (a non-STEC strain) persisted longer in wilted wheat silage than in nonwilted wheat silage, presumably due to the slower $\mathrm{pH}$ decline of the wilted silage. Furthermore, different studies showed that STEC can survive and grow in aerobically deteriorated silage provided that the $\mathrm{pH}$ of the material is higher than 5.0 (Pedroso et al., 2010; Dunière et al., 2011; Ogunade et al., 2016, 2017). These findings indicate that contamination of silage by STEC is possible during phases when the silage is prone to aerobic deterioration, for instance during feed-out. Air ingress into silos during such periods may lead to significant growth of STEC and may contribute to the cycling of the pathogen on dairy farms. 
The presumed major route of transmission of STEC to raw milk is contamination during milking from feces, as described previously for spores of C. botulinum and $B$. cereus. An alternative transmission route is from cows suffering from mastitis caused by STEC (Lira et al., 2004), but the significance of this route compared with fecal contamination is currently unknown.

\section{Mycobacterium bovis}

Bovine tuberculosis is a zoonotic disease of global concern due to an increasing number of infected herds, especially in developing countries, and its adverse effects on animal production and human health (FAO, 2015). Phillips (2005) reviewed evidence for survival of Mycobacterium bovis in silage and concluded that, although little direct evidence exists, conditions prevailing in the silo may allow the organism to survive in an encysted state of dormancy. Growth of $M$. bovis BCG was inhibited at $\mathrm{pH}$ values below 5.0 and increased linearly to $\mathrm{pH} 7$ (Rao et al., 2001); thus, growth is likely to be encouraged at the relatively high $\mathrm{pH}$ levels associated with aerobically deteriorated silage

Grass and especially grain-bearing forage maize and whole-cereal crops can be contaminated in the field preharvest, at the silo feed-out face, and in the feed trough (Garnett et al., 2002) with M. bovis shed by diseased wildlife (e.g., badgers, Meles meles). Where necessary and if feasible, steps should be taken to prevent access of wildlife to the exposed silo feed-out face and feed troughs.

\section{Molds}

Molds that occur in silages can be differentiated between those associated with crop infestations during growth in the field, such as Fusarium and Alternaria species; Aspergillus flavus and Aspergillus parasiticus; molds that are endophytic symbionts in grasses or cereals, such as Claviceps and Neotyphodium species; and molds that develop in poorly managed silage, such as Penicillium roqueforti and Penicillium paneum, Aspergillus fumigatus, Monascus ruber, Byssochlamys nivea, Rhizopus nigricans, and Chrysonilia sitophila (Pelhate, 1977; CAST, 2003; Driehuis, 2013). Development of the latter group most often occurs during silage storage or feed-out and usually results from aerobic deterioration (Driehuis, 2013). With the exception of $R$. nigricans and $C$. sitophila, all the molds listed here are capable of producing mycotoxins (CAST, 2003; Driehuis, 2013).

Mycotoxins are ubiquitously present in forages and feeds. In a global survey of aflatoxins, deoxynivalenol, zearalenone, ochratoxin A, and fumonisins in feed and feed commodities, $72 \%$ of the samples contained detectable levels of 1 or more of these mycotoxins (Schatzmayer and Streit, 2013). Mycotoxins in feeds are of dual concern. First, they can be hazardous to animal health and cause production losses, which can have a large economic impact. Second, they can be hazardous to the safety of food products of animal origin. Of the major mycotoxins in silage crops, the second concern holds true only for aflatoxin, as is described later in this paper. The occurrence of mycotoxins in silage, detoxification strategies, ruminal degradation, and carry-over of mycotoxins to milk in dairy cattle and toxic effects in cattle have been reviewed previously (Fink-Gremmels, 2008; Driehuis, 2013; Flores-Flores et al., 2015) as well as elsewhere in this silage special issue (Ogunade et al., 2018). Aspergillus fumigatus is considered a health hazard not only because of the mycotoxins that are potentially produced by this mold in silage, but also because inhalation of spores of this mold can cause disease (aspergillosis) in humans and animals. Feeding silage or hay that is contaminated with A. fumigatus to cattle can cause bovine aspergillosis (Smith and Lynch, 1973; Sarfati et al., 1996). In humans with altered lung function, such as asthma and cystic fibrosis patients, A. fumigatus can cause a hypersensitive response in the lungs, a disease known as Farmers Lung. In immunecompromised individuals, this mold can cause severe infections (invasive aspergillosis; Dagenais and Keller, 2009). Puntenney et al. (2002) suggested that A. fumigatus is a risk factor for hemorrhagic bowel syndrome in dairy cows; however, no subsequent study has verified this theory.

\section{PLANT TOXINS AND ERGOT ALKALOIDS}

This section describes health hazards from phytoestrogens, pyrrolizidine alkaloids, mimosine, tropane alkaloids, tropolone alkaloids, ergot alkaloids, and prussic acid.

\section{Phytoestrogens}

Phytoestrogens are plant compounds that are similar to animal estrogens in structure and function (Pace et al., 2006). Phytoestrogens mainly include coumestans, ligans, and isoflavones (Branca and Lorenzetti, 2005). Coumestans, including coumestrol, are found in several plants but are more commonly found in alfalfa (Medicago sativa) and clover (Trifolium spp.) than other forage species (Murkies et al., 1998). Coumestans are the most potent estrogen of all known phytoestrogens (Moravcová et al., 2004). Phytoestrogens were first discovered to cause fertility problems, including reduced 
fertility and lambing percentage, in sheep grazing subterranean clover (Bennetts et al., 1946). In sheep, consuming phytoestrogens can result in temporary or even permanent infertility (Adams, 1995). Similar effects of phytoestrogens were also reported in cattle fed diets containing alfalfa or red clover (Trifolium pratense) (Lookhart, 1980; Kallela et al., 1984). Lookhart (1980) reported reduced udder development and vaginal and cervical prolapse in cattle fed haylage containing 37 $\mathrm{mg}$ of coumestrol $/ \mathrm{kg}$ of DM. Moreover, Kallela et al. (1984) observed serious fertility problems in heifers fed ensiled red clover containing high levels of estrogenic isoflavone.

The results of studies on the fate of phytoestrogens during ensiling of red clover have been equivocal. Kallela (1975) reported increased phytoestrogen concentration after ensiling red clover. Similarly, Sarelli et al. (2003) reported that phytoestrogen concentration increased from 8 to $11 \mathrm{~g} / \mathrm{kg}$ of DM after ensiling red clover for 4 mo. In contrast, Sivesind and Seguin (2005) observed a $22 \%$ reduction in the concentration of total isoflavone in red clover ensiled for $50 \mathrm{~d}$. In a recent study, Daems et al. (2016) reported reduced concentrations of 4 isoflavones, daidzein, genistein, biochanin A, and formononetin, by $26,39,66$, and $73 \%$, respectively, in red clover ensiled for $2 \mathrm{wk}$. The inconsistent results in the literature may be attributed to differences in factors such as different cultivars, stage of crop maturity at cutting, extent of wilting, phytoestrogen concentration before ensiling, temperature, duration of ensiling, and silage additives.

Limited information is available on the effect of ensiling on the stability of phytoestrogen in alfalfa. Moravcová et al. (2003) reported that the concentration of coumestrol decreased from 200 to 44 and 20 $\mathrm{mg} / \mathrm{kg}$ after ensiling for 76 and $110 \mathrm{~d}$, respectively. Decomposition of this phytoestrogen was not affected by applying an inoculant (mixture of Enterococcus faecium and Lactobacillus rhamnosus), sucrose, or formic acid. In a similar study, Moravcová et al. (2004) reported that most of coumestrol was degraded in alfalfa ensiled for $50 \mathrm{~d}$, but the degradation was dependent on cultivar and maturity. The cultivar Morava had lower concentrations of coumestrol than the cultivar Palava after more than $120 \mathrm{~d}$ of ensiling. Moreover, maturity might have also played a role, as they reported that Palava harvested in October had higher concentration of coumestrol than that harvested in May after $61 \mathrm{~d}$ of ensiling. Overall, ensiling can be a potential strategy to reduce phytoestrogens, but further studies are needed to establish the best combinations of cultivar, plant maturity, and ensiling conditions that will ensure extensive reduction of phytoestrogens.

\section{Pyrrolizidine Alkaloids}

Pyrrolizidine alkaloids (PA) are heterocyclic compounds that are mostly derived from necine bases, esters of basic alcohols (Fu et al., 2004). They exist in a variety of plants, such as those belonging to the families Boraginaceae, Compositae, and Leguminosae, and can cause poisoning in humans and livestock (Cheeke, 1988). Within these families, Boraginaceae Heliotropium (known as heliotropes), Compositae $\mathrm{Se}$ necio (includes ragworts), and Leguminosae Crotalaria (known as rattlepods) are the major species of concern (Prakash et al., 1999). Pyrrolizidine alkaloids cause cirrhosis of liver in humans (Willmott and Robertson 1920; Steyn, 1933) and liver and lung poisoning in rats, horses, sheep, and cattle (Mattocks 1968; McLean, 1970). Small herbivores, such as sheep, goats, and rabbits, are known to be more resistant to PA toxicity than large species such as cattle and horses (Cheeke, 1988). Seaman and Walker (1985) reported PA poisoning in cattle and horses consuming Senecio madagascariensis, Echium plantagineum, and Heliotropium europaeum. Seaman (1987) reported mortalities in sheep grazing Echium plantagineum and Heliotropium europaeum. In addition, it has been reported that all calves fed Senecio riddellii at a rate of $45 \mathrm{mg}$ of $\mathrm{PA} / \mathrm{kg}$ of $\mathrm{BW}$ for $20 \mathrm{~d}$ exhibited toxicity (Molyneux et al., 1991). In some regions, such as the State of Rio Grande do Sul in Brazil, PA poisoning was reported as the most frequent cause of poisoning in cattle (Karam and Motta, 2011).

Ensiling can partly degrade PA by enzymatic decomposition (Berendonk et al., 2010) to nontoxic necines and necic acids (Culvenor et al., 1976; Mattocks, 1986). However, effects of ensiling on degradation of PA is dependent on the plant part ensiled (Chizzola et al., 2015), plant maturity (Berendonk et al., 2010), and contamination level of PA-containing weeds (Candrian et al.,1984; Becerra-Jiminez et al., 2013). Chizzola et al. (2015) reported no change in concentration of PA in leaves and stems of marsh ragwort (Jacobaea/Senecio spp.), whereas up to an $86 \%$ reduction was observed in the flower heads after ensiling. Similarly, Berendonk et al. (2010) reported reduction in the concentration of PA in tansy ragwort (Senecio jacobaea L.) silages; however, the level of degradation was higher in silage made at the flowering stage (up to 95\%) compared with at the rosette stage (less than 20\%). In another study, Candrian et al. (1984) reported that 54.3 to $95.5 \%$ of PA was destroyed by ensiling pure tansy ragwort (Senecio alpinus L.) or grass/clover silage mixed with 3.5 to $100 \%$ tansy ragwort. The PA degradation level was much lower $(54.3 \%)$ when the contamination level was low (3.5\%). Similarly, ensiling for $90 \mathrm{~d}$ decreased 
concentration of PA by 56 to $69 \%$ in Lolium perenne contaminated with 25 to $75 \%$ ragwort (Senecio jacobaea), but negligible decomposition occurred when the level of contamination was 1 to $10 \%$ (Becerra-Jiminez et al., 2013).

\section{Mimosine}

Mimosine is a nonprotein AA with a similar structure to tyrosine (Angthong et al., 2007). It is toxic to animals as an antagonist to tyrosine that inhibits protein biosynthesis, thus causing symptoms such as reduced animal production. Leucaena, a mimosine-containing tropical legume (Shelton and Brewbaker, 1998), was recognized as the "miracle tree" during the 1970s and early 1980s due to its long life and high nutritional value (Shelton and Brewbaker, 1998); however, its mimosine content limited its use as a livestock feed (Hammond, 1995; Shelton and Brewbaker, 1998). Jones and Hegarty (1984) reported no adverse effect on thyroid function or feed intake when steers were fed a diet containing Leucaena at less than $10 \mathrm{~g} / \mathrm{kg}$ of DM; however, hypothyroidism and reduced feed intake was observed when levels exceeded $10 \mathrm{~g} / \mathrm{kg}$ of DM. Moreover, Jones et al. (1976) reported that cattle grazing on Leucaena pasture experienced enlarged thyroid glands.

Ensiling of Leucaena has been documented as an effective technique to preserve the forage and reduce its mimosine content. Sunagawa et al. (1989) reported a $90 \%$ reduction in mimosine content after 14 to $21 \mathrm{~d}$ of ensiling. Similarly, Angthong et al. (2007) showed that ensiling Leucaena leucocephala leaf with $20 \%$ rice bran for up to $81 \mathrm{~d}$ reduced mimosine content by over $90 \%$. In addition, Srinivasulu et al. (2000) reported 31.2, 35.3 , and $65.8 \%$ degradation of mimosine when L. leucocephala was ensiled for 30, 45, and $60 \mathrm{~d}$, respectively. Furthermore, Chen et al. (2014) reported that addition of sucrose at $2 \%$ fresh weight to Leucaena at ensiling increased the extent of degradation of mimosine (49 vs. $25.5 \%)$ as compared with when it was not added. Those authors observed a negative correlation between mimosine degradation rate and $\mathrm{pH}$ and a positive correlation between the degradation rate and lactic acid content. The reduction in mimosine concentration after ensiling may therefore be related to the decrease in $\mathrm{pH}$ and increase in lactic acid concentration that occurred after ensiling. In a recent study, 85 to $90 \%$ of mimosine was degraded after ensiling of Leucaena for $28 \mathrm{~d}$ (Phesatcha and Wanapat, 2015).

\section{Tropane Alkaloids}

Tropane alkaloids are a group of bicyclic alkaloids and secondary metabolites that contain a tropane ring in their chemical structure (O'Hagan, 2000). Tropane alkaloids exist naturally in jimsonweed (Datura stramonium), which can contaminate hay and silage (Cortinovis and Caloni, 2013). In the United States, jimsonweed is a serious threat to soybeans (Glycine max), and it is one of the costliest weeds to control in eastern states such as Virginia and North Carolina. All parts of the jimsonweed are toxic, with the ripe seed containing the highest amount of alkaloids with strong anticholinergic properties (Chang et al., 1999; DeFrates et al., 2005; Soler-Rodríguez et al., 2006). The toxic tropane alkaloids in jimsonweed include hyoscyamine, atropine, and scopolamine (DeFrates et al., 2005). All livestock species have similar clinical signs of jimsonweed poisoning, including dry mouth, mydriasis, tachycardia, incoordination, convulsion, and coma (Anadón et al., 2012).

Little information is available on the stability of tropane alkaloids during ensiling. Binev et al. (2006) reported $100 \%$ mortality because of tropane alkaloid poisoning in 34 horses fed ensiled corn contaminated with jimsonweed, suggesting that tropane alkaloids might survive the ensiling process. However, more studies are needed to understand the stability of tropane alkaloids during ensiling.

\section{Tropolone Alkaloids}

Autumn crocus (Colchicum autumnale), also known as meadow saffron, is one of the prominent alkaloidproducing poisonous plants (Beyer et al., 2009). Autumn crocus contains several tropolone alkaloids, with colchicine being the most abundant, accounting for 50 to $70 \%$ of all tropolone alkaloids. Other less abundant tropolone alkaloids include colchicoside, demecolcine, and a variety of related tropolone derivatives (Kupper at al., 2010). In autumn crocus, the overall alkaloid concentration ranges from 1 to $20 \mathrm{~g} / \mathrm{kg}$ of $\mathrm{DM}$, with highest colchicine concentration occurring in flowers (12 to $20 \mathrm{~g} / \mathrm{kg}$ of DM) and seed ( 5 to $12 \mathrm{~g} / \mathrm{kg}$ of DM), but the whole plant is considered toxic (Kupper et al., 2010). Clinical signs of colchicine poisoning include gastrointestinal symptoms, such as fluid losses, peripheral leukocytosis, and more severe complications, including heart and renal failure, respiratory distress, hepatic injury, and neuromuscular involvement (Brvar et al., 2004). Yamada et al. (1998) reported severe diarrhea and eventual death within $3 \mathrm{~d}$ in eleven 4 to 7 mo old calves fed $12 \mathrm{~g}$ of crude or dehydrated autumn crocus per kilogram of BW.

To our knowledge, only 1 study reported the effects of ensiling on concentration of tropolone alkaloids. Chizzola et al. (2015) determined the level of tropolone alkaloids in autumn crocus after ensiling for 18 to $43 \mathrm{wk}$ and reported a wide range of degradation (0 to 
$30 \%)$. More research on the degradation of tropolone alkaloids is needed.

\section{Ergot Alkaloids}

Ergot alkaloids are mycotoxins produced by grass endophytic fungi (Claviceps spp., Neotyphodium spp., and so on) in forages such as tall fescue (Festuca arundinacea), sorghum, and ryegrass (Mostrom and Jacobsen 2011). It is estimated that tall fescue toxicosis costs the US beef industry $\$ 0.5$ to $\$ 1$ billion each year due to reduced births and reduced weight gain of beef cattle (Comis, 2000).

Dihydroergosine is the major ergot alkaloid present in sorghum infected by Claviceps africana (Molloy et al., 2003), whereas ergovaline is the major ergot alkaloid produced by endophyte Neotyphodium spp. in tall fescue and ryegrass (TePaske et al., 1993; Panaccione at al., 2001; Crews, 2015). In 1994, outbreaks of ergot toxicosis in Africa were reported in cattle that ingested diets contaminated with ergotized annual ryegrass seed; approximately 2,646 dairy cows had reduced milk production, weight loss, and reduced fertility (Schneider et al., 1996). Two dairy herds in South Africa consuming corn silage developed hyperthermia and experienced $30 \%$ loss of milk production; a novel endophyte, Claviceps cyperi, and up to $0.98 \mathrm{mg} / \mathrm{kg}$ of total ergot alkaloids were discovered in the corn silage (Naudè et al., 2005). In addition, Lean (2001) reported that lactating dairy cows consuming perennial ryegrass silage containing $1.78 \mathrm{mg} / \mathrm{kg}$ of total ergovaline experienced reduced reproductive performance, increased incidence of mastitis, and decreased milk yield. Blaney et al. (2000) summarized several cases and suggested that signs of ergot alkaloid toxicity include feed refusal and severe declines in milk yield.

Varying effects of ensiling on ergot alkaloid concentration have been reported, and most studies have been on tall fescue grass. Turner et al. (1993) reported no effect of ensiling for $60 \mathrm{~d}$ on ergovaline concentrations $(0.15$ to $0.20 \mathrm{mg} / \mathrm{kg}$ ) of tall fescue. In addition, Roberts et al. (2002) reported no effect of ensiling on concentration of total ergot alkaloids (0.94 to $1.24 \mathrm{mg} / \mathrm{kg}$ ) of tall fescue infected with Neotyphodium coenophialum after $42 \mathrm{~d}$ of ensiling. In contrast, Mikołajczak et al. (2005) reported that $2.63 \mathrm{mg} / \mathrm{kg}$ of ergovaline was completely degraded after $140 \mathrm{~d}$ of ensiling of tall fescue infected with N. coenophialum. Similarly, Blaney et al. (2010) reported almost $50 \%$ degradation of dihydroergosine ( 0.85 to $0.46 \mathrm{mg} / \mathrm{kg}$ ) in sorghum ensiled for $42 \mathrm{~d}$. Furthermore, Roberts et al. (2011) reported that ensiling tall fescue for $90 \mathrm{~d}$ reduced the ergovaline concentration by 57 and $60 \%$ in 2 experiments but increased concentration of total ergot alkaloids. Similarly, Roberts et al. (2014) reported decreased ergovaline concentration (24 to 58\%) in tall fescue ensiled for 100 d. However, increased concentrations of total ergot alkaloids in high-moisture tall fescue were observed. The reason for the increase in total ergot alkaloids is most probably because the degradation products of ergovaline, such as lysergic acid (Fribourg et al., 2009), also contributed to the total alkaloid concentration. Thus, ensiling is not recommended as a reliable method to degrade ergot alkaloids to a safe level due to inconsistency in degrading ergovaline and total ergot alkaloids in previous studies.

Hay and ammoniated hay contained less total ergot alkaloids than silage made from tall fescue (Roberts et al., 2002, 2011). Thus, haymaking or treating hay with anhydrous ammonia may be an approach to reduce ergot alkaloids of forage as noted by Roberts et al. (2011). More research is needed to assess the best ensiling conditions that ensure extensive degradation of ergot alkaloids in forages.

\section{Prussic Acid}

Prussic acid, also called hydrocyanic acid, is a highly toxic compound derived from decomposition process of nontoxic cyanide and glucosides in cyanogenic plants such as sorghum and Sudan grass (Toaima et al., 2014). Stressful environmental conditions, such as those pertaining to the soil, climate, or storage, that retard normal development of sorghum favor the production of prussic acid in subsequent growth (Franzke et al., 1939). Signs of prussic acid poisoning in ruminant animals include increased respiration, irregular pulse, staggering, and frothing at the mouth, or respiratory paralysis or even death (Gray et al., 1968; Barnhart and Dewell, 2011).

Franzke et al. (1939) reported 3.4 to $88.4 \%$ reduction in prussic acid concentration after ensiling whole sorghum plants with different maturity levels for different lengths of time. In their study, despite the large variation in the initial concentration of prussic acid (590-3,860 $\mathrm{mg} / \mathrm{kg})$, the final concentrations ranged from 400 to $500 \mathrm{mg} / \mathrm{kg}$ in 3 experiments. Those authors suggested that harvest date and sorghum maturity might affect the degradation of prussic acid. Briese and Couch (1940) reported that $29.7 \%$ of the prussic acid in sorghum was lost after $120 \mathrm{~d}$ of ensiling. In addition, McCarty et al. (1971) reported that ensiling for $28 \mathrm{~d}$ totally degraded the prussic acid in sorghum forage. Kallah et al. (1997) observed that prussic acid concentration of Sorghum almum forage was reduced from 300 to $474 \mathrm{mg} / \mathrm{kg}$ of DM to between 183 and 244 $\mathrm{mg} / \mathrm{kg}$ of DM after ensiling for $21 \mathrm{~d}$. All these studies reported that ensiling reduced the concentration of prussic acid. 
The effects of ensiling on prussic acid degradation in other plant species have also been reported. Ngwa et al. (2004) reported that ensiling pods of Acacia sieberiana, a predominant browse species in sub-Saharan Africa, for $35 \mathrm{~d}$ reduced the prussic acid concentration from 131 to $18 \mathrm{mg} / \mathrm{kg}$ of DM and that moisture concentration at ensiling affected the response. Prussic acid was degraded faster when the moisture concentration was high (60\%) compared with when it was low (40\%). Ty et al. (2001) reported a reduction of prussic acid concentration from 73 to $20 \mathrm{mg} / \mathrm{kg}$ of fresh weight after 56 $\mathrm{d}$ of ensiling of cassava foliage. Similarly, Pinho et al. (2004) observed that ensiling the aerial part of cassava for $30 \mathrm{~d}$ reduced prussic acid concentration from 7 to $1.9 \mathrm{mg} / \mathrm{kg}$ of fresh weight. Additionally, Kavana et al. (2005) reported that ensiling cassava leaves for $90 \mathrm{~d}$ reduced the prussic acid concentration from 289 to 20 $\mathrm{mg} / \mathrm{kg}$, which is similar to the reduction reported by Lounglawan et al. (2011) after $28 \mathrm{~d}$ of ensiling. These studies show that ensiling can be used to reduce the prussic acid concentration, but the extent of reduction varies with other factors. Therefore, caution is needed to ascertain the level of prussic acid in the silage before it is fed to animals. Different authors have noted that much of the prussic acid escapes in the gaseous form when the silage is moved or fed (Miller and Stroup, 2004; Vough and Cassel, 2006); however, no data on such losses was found in the literature.

\section{CHEMICAL HAZARDS}

\section{Nitrate, Nitrite, and Oxide Gases of Nitrogen}

Nitrate $\left(\mathrm{NO}_{3}^{-}\right)$is an important crop component because of its dual role as a macronutrient and as a signal for plant tissue growth (Crawford, 1995). Nitrate concentrations in crops harvested in early spring can be elevated due to uptake by the plant of fertilizer $\mathrm{N}$ and soil $\mathrm{N}$ following mineralization (Bolan and Kemp, 2003), especially in situations of low environmental temperatures that decrease the rate of plant tissue protein synthesis (Lawlor et al., 1988; Bolan and Kemp, 2003). Drought is associated with increased concentrations of $\mathrm{NO}_{3}{ }^{-}$in crops due to reduced photosynthesis linked to decreased tissue nitrate reductase activity (Foyer et al., 1998).

Nitrate itself is not toxic to livestock, but poisoning by nitrite $\left(\mathrm{NO}_{2}^{-}\right)$can follow the consumption of forages containing high concentrations of $\mathrm{NO}_{3}^{-}$. The normal conversion pathway of $\mathrm{NO}_{3}{ }^{-}$in the rumen is by reduction to ammonia $\left(\mathrm{NH}_{3}\right)$ with $\mathrm{NO}_{2}{ }^{-}$as an intermediary. However, in situations of high $\mathrm{NO}_{3}{ }^{-}$intake, $\mathrm{NO}_{2}{ }^{-}$can accumulate in the rumen and be absorbed into blood, where it reacts with hemoglobin to produce methemo- globin, which cannot carry oxygen from lungs to tissues. Methemoglobinemia is the term used to describe the condition, which can present in a range of severities including reduced feed intake, abortion, respiratory distress, coma, and even sudden death (Bolan and Kemp, 2003; Binta and Mushi, 2012; Lee and Beauchemin, 2014; Rasby et al., 2014). Stored forages with $\mathrm{NO}_{3}{ }^{-}$ concentrations in excess of $1,700 \mathrm{mg}$ of $\mathrm{NO}_{3}{ }^{-}-\mathrm{N} / \mathrm{kg}$ of DM may cause acute toxicity and should be given to livestock in a ration balanced with other feeds (Adams et al., 2016) to dilute the toxicity.

Nitrate concentration is decreased in silage, relative to its concentration in the crop at harvest, due to fermentation (Khorasani et al., 1997). Nitrate is degraded early in the ensiling period by enterobacteria and lactic acid bacteria. End products of $\mathrm{NO}_{3}{ }^{-}$degradation in silage are $\mathrm{NH}_{3}$ and nitrous oxide $\left(\mathrm{N}_{2} \mathrm{O}\right)$ gas, with nitrogen dioxide $\left(\mathrm{NO}_{2}\right)$ and nitric oxide (NO) gases occurring as intermediates (Pahlow et al., 2003; Rooke and Hatfield, 2003). A positive consequence of the reduction of $\mathrm{NO}_{3}{ }^{-}$ to $\mathrm{NO}_{2}{ }^{-}$is prevention of clostridial growth. However, if $\mathrm{NO}_{2}{ }^{-}$is degraded completely to $\mathrm{NH}_{3}$, silage $\mathrm{pH}$ can remain relatively high $(>\mathrm{pH} 4.5)$ and, consequently, acidification may be insufficient to prevent clostridial growth during the storage period, especially at low DM concentrations (Spoelstra, 1983).

Production of nitric oxide and nitrogen dioxide gases in silage is a serious risk to livestock and human health and the respiratory hazard, known as silo-fillers' disease has been recognized for many years (Grayson, 1956). The reduction of $\mathrm{NO}_{3}{ }^{-}$to nitric oxide, a colorless gas, is followed by its oxidation on exposure to air to nitrogen dioxide, a yellow to reddish-brown gas with an irritating odor that is heavier than air and stays close to the ground level or to the sides of the silo. Nitric oxide and nitrogen dioxide react with water in air to form nitrous and nitric acid gases, respectively. Inhalation of these gases damages lung tissue and causes respiratory distress leading to asphyxiation.

O'Kiely et al. (1999) described an incident in which 10 calves and the farmer suffered severe respiratory distress $24 \mathrm{~h}$ after an adjacent silo had been filled with grass. A brown haze of nitrogen dioxide gas was seen in the building next to the silo. The crop had received liquid cattle manure (slurry) at 34,000 L per hectare about 14 wk preharvest and $140 \mathrm{~kg}$ of fertilizer nitrogen per hectare in 2 applications about 13 and 9 wk preharvest. Samples taken from the front of the silo beneath the polyethylene film covering revealed an intensely yellow colored layer beneath normal green-colored silage. The characteristics of the 2 types of silage are in Table 3. Features of the yellow silage were very high $\mathrm{CP}$, extremely low $\mathrm{pH}$, low concentrations of fermentation acids, low buffering capacity, and reduced digestibility in 
vitro, indicative of nitric acid contamination. Livestock should not be housed and people should not work close to silos that are emitting oxide gases of nitrogen during or immediately after filling.

\section{Butyric Acid}

Butyric acid can be present in poorly fermented silage from the fermentation of water-soluble carbohydrates and lactic acid, principally by clostridia that are present on the crop at harvest. These endospore-forming obligate anaerobic bacteria can develop in poorly made silage during the storage period in the silo and during feed-out to produce a range of undesirable products in addition to butyric acid, including amines, $\mathrm{NH}_{3}$, acetic acid, carbon dioxide, and hydrogen (Pahlow et al., 2003). The growth of clostridia in silage can be associated with significant livestock health issues as a result of (1) reduced silage intake and absorption of butyric acid from rumen into blood can increase the risk of clinical ketosis (acetonaemia) and (2) the development of pathogenic Clostridium botulinum in silage.

The growth of clostridia is encouraged in low-DM silage $(<250 \mathrm{~g}$ of $\mathrm{DM} / \mathrm{kg}$ of fresh weight $)$ with a $\mathrm{pH}$ above 4.2 in the case of $C$. tyrobutyricum, which ferments lactic acid to butyric acid, hydrogen, and carbon dioxide, or in silage with $\mathrm{pH}$ above 5.0 for C. sporogenes, which ferments both carbohydrates and proteins with the production, inter alia, of amines and $\mathrm{NH}_{3}$ (see above; Driehuis, 2013). The risk to livestock health from butyric acid in poorly fermented silage is mainly linked to ketosis associated directly with consumption of silage butyric acid and indirectly with reduced energy intake from the silage component of the diet.

Oetzel (2007) reviewed the etiology of clinical ketosis in dairy cows and identified 3 types, all characterized by elevated concentrations of serum $\beta$-hydroxybutyric acid $(>1200 \mu \mathrm{mol} / \mathrm{L})$ : (1) type 1 ketosis, 3 to $6 \mathrm{wk}$

Table 3. Characteristics of normal (green) and intensely yellow forage taken from the front of a bunker silo $4 \mathrm{~d}$ after ensiling (including data from O'Kiely et al., 1999)

\begin{tabular}{lcc}
\hline & \multicolumn{2}{c}{ Color of silage } \\
\cline { 2 - 3 } Item & Normal (green) & Yellow \\
\hline $\mathrm{DM}, \mathrm{g} / \mathrm{kg}$ & 214 & 194 \\
$\mathrm{pH}$ & 4.3 & 1.1 \\
Nitrate, $\mathrm{mg} / \mathrm{L}$ & 400 & 501 \\
Crude $\mathrm{protein}, \mathrm{g} / \mathrm{kg}$ of DM & 193 & 294 \\
$\mathrm{NH}_{3}$-N, g/kg of total N & 94 & 31 \\
Lactic acid, g/kg of DM & 66 & 9 \\
Acetic acid, g/kg of DM & 21 & 8 \\
Ethanol, g/kg of DM & 6 & 18 \\
Buffering capacity, mEq/kg of DM & 686 & 97 \\
Digestibility of DM in vitro, g/kg & 700 & 573 \\
\hline
\end{tabular}

Table 4. Risk factors for butyric acid silage ketosis in dairy cows (data from Oetzel, 2007)

\begin{tabular}{ll}
\hline & $\begin{array}{l}\text { Risk factors for butyric } \\
\text { acid silage ketosis in } \\
\text { dairy cows }\end{array}$ \\
\hline Item & $\begin{array}{l}\text { Alfalfa, clover, ryegrass, } \\
\text { haycrop }\end{array}$ \\
Silage & $<250 \mathrm{~g} / \mathrm{kg}$ of fresh weight \\
DM & $>4.4 \mathrm{~g}$ \\
$\mathrm{pH}$ & $>10 \mathrm{~g} / \mathrm{kg}$ of DM \\
Butyric acid & $>5 \mathrm{~kg}$ of DM $/ \mathrm{cow}$ \\
Daily intake of silage & $<50 \mathrm{DIM}$ \\
Stage of lactation & $>50 \mathrm{~g} / \mathrm{cow}$ \\
Daily intake of butyric acid from silage
\end{tabular}

postcalving, associated with chronic hypoglycemia; (2) type 2 ketosis, principally a consequence of excessive mobilization of fat tissue and compromised liver gluconeogenesis; and (3) butyric acid silage ketosis. Risk factors for the development of butyric acid silage ketosis are in Table 4. Butyric acid in poorly fermented silage adds to that produced by rumen fermentation. Addition of $200 \mathrm{~g}$ of butyric acid to the diet was reflected in elevated concentrations of the ketone body acetoacetate in plasma (Lingaas and Tveit, 1992). If butyric acid silage ketosis is suspected in cows less than 50 DIM or ketosis is confirmed by analysis of $\beta$-hydroxybutyric acid in blood, silage should be analyzed for individual VFA to determine daily intake of butyric acid from silage, which should be less than $50 \mathrm{~g}$ of butyric acid/d (Oetzel, 2007). Butyric acid silage should not be given to close up dry cows or newly calved cows, but given instead to other classes of livestock. In extreme situations, the silage may be used as a crop fertilizer and not as animal feed.

\section{Biogenic Amines and Ammonia}

Biogenic amines (i.e., amines with biological activity) occur in silage, some with potentially detrimental effects to feed intake and animal health. The formation of amines is via peptide bond hydrolysis and involves the enzymatic decarboxylation of free AA by the action of plant proteases and peptidases and bacterial enzymes. The amines of concern, including histamine, tyramine, putrescine, cadaverine, spermine, and spermidine, are associated with headaches, nausea, vomiting, diarrhea, and hypertension in humans (Ladero et al., 2010; Gardini et al., 2016) and can accumulate in dairy products, especially cheese (Linares et al., 2011).

The main risk factors for the production of amines in silage are slow acidification following ensiling (Van Os et al., 1996). Amines formed in the early stage of ensiling are probably due to decarboxylation of AA by enterobacteria during the initial aerobic phase, whereas 
those formed later in the ensiling period are the result of subsequent growth of proteolytic clostridia species, including C. sporogenes and Clostridium bifermentans (McDonald et al., 1991; Pahlow et al., 2003; Rooke and Hatfield, 2003). Amines can be formed in both grass and maize silages, with putrescine, cadaverine, and spermidine predominating in silages made from both crop species (Krízek, 1993; Krízek et al., 1993). Direct acidification with formic acid and inoculation with lactic acid bacteria (Lactobacillus plantarum, Lactobacillus casei) can suppress amine formation (Krízek, 1993; Steidlová and Kalac, 2004; Nishino et al., 2007), probably by inhibiting proteolytic bacteria.

Poorly fermented silages have elevated concentrations of amines and $\mathrm{NH}_{3}$, which might be contributory factors to reduced silage intake and utilization by the animal. Cadaverine was correlated with reduced intake of alfalfa silage in a short-term feeding study despite evidence of its extensive metabolism to $\mathrm{NH}_{3}$ in the rumen (Phuntsok et al., 1998). Scherer et al. (2015) reviewed research into the effect of amines on silage intake and concluded that the data were inconsistent, possibly due to differences in daily dose, degradation of amines to $\mathrm{NH}_{3}$ in the rumen (Van Os et al., 1995), and whether or not the animal was adapted to amines in the diet (Van Os et al., 1997).

Ammonia, from AA deamination and from the reduction of $\mathrm{NO}_{3}$ and $\mathrm{NO}_{2}$, is diagnostic of poorly fermented silages, with concentrations of $\mathrm{NH}_{3}-\mathrm{N}$ exceeding $100 \mathrm{~g} /$ $\mathrm{kg}$ of total $\mathrm{N}$ leading to increased risk of rumen ammonia concentrations above maximum levels for optimal microbial protein synthesis (McDonald et al., 1991). Hazards to animal production and health are excess $\mathrm{NH}_{3}$ absorption from rumen into liver and leakage into peripheral blood, rather than through a direct effect of $\mathrm{NH}_{3}$ on silage intake (Weiss et al., 2003). Conversion of ammonia to urea in the liver before its excretion in urine entails a loss of $23 \mathrm{~kJ}$ of energy/g of N (Martin and Blaxter, 1965). For example, the excretion by a dairy cow of $190 \mathrm{~g}$ of urinary N/d (Kauffman and St-Pierre, 2001), is equivalent to an energy loss of 4.4 $\mathrm{MJ} / \mathrm{d}$. Also of concern is impaired fertility of animals, with elevated concentrations of urea in blood reflecting high intakes of degradable protein (Jordan et al., 1983; Elrod and Butler, 1993).

\section{CONCLUSIONS}

The probability of occurrence in silage of the chemical and microbiological health hazards described in this paper can be mitigated by proper silage-making practices. Presence of $C$. botulinum toxins and high levels of butyric acid or biogenic amines can be prevented by achieving a rapid reduction in silage $\mathrm{pH}$ to $<4.5$, or a significant reduction in water activity by rapid field wilting before ensiling. Low silage $\mathrm{pH}$ levels also restrict growth of enterobacteria, which reduces the risk of the production of toxic oxide gases of nitrogen from nitrate. Growth of L. monocytogenes, STEC, and molds can be prevented by prevention of aerobic deterioration, which can be achieved by maintaining anoxic conditions during storage of silage and by restricting exposure to and ingress of air after opening a silage silo for feeding. Chemical and biological silage additives can assist in achieving a rapid reduction in silage $\mathrm{pH}$ and preventing aerobic deterioration, as described previously. The presence of plant toxins in silage is either associated with the natural occurrence of toxic substances in certain forage crops or with the contamination of forages by toxin-containing plants. More research is needed to increase our understanding of the effect of plant toxins on animal health and to develop technologies to degrade or detoxify these toxins in silage or in the animal's diet.

\section{REFERENCES}

Adams, N. R. 1995. Detection of the effects of phytoestrogens on sheep and cattle. J. Anim. Sci. 73:1509-1515.

Adams, R. S., T. R. McCarty, and L. J. Hutchinson. 2016. Prevention and control of nitrate toxicity in cattle. Penn State College of Agricultural Sciences, Cooperative Extension. DAS 92-107. Accessed Nov. 7, 2016. http://extension.psu.edu/animals/dairy/nutrition/ forages / mycotoxins-nitrates-and-other-toxicity-problems / prevention-and-control-of-nitrate-toxicity-in-cattle-1.

Anadón, A., M. R. Martínez-Larrañaga, and V. Castellano. 2012. Poisonous plants of Europe. Pages 1080-1094 in Veterinary Toxicology: Basic and Clinical Principles, 2nd ed. R. C. Gupta, ed. Academic Press, Cambridge, MA.

Anderson, N. M., J. W. Larkin, M. B. Cole, G. E. Skinner, R. C. Whiting, L. G. Gorris, A. Rodriguez, R. Buchanan, C. M. Stewart, J. H. Hanlin, L. Keener, and P. A. Hall. 2011. Food safety objective approach for controlling Clostridium botulinum growth and toxin production in commercially sterile foods. J. Food Prot. 74:1956-1989.

Angthong, W., B. Cheva-Isarakul, S. Promma, and B. Cheva-Isarkul. 2007. Beta-carotene, mimosine and quality of leucaena silage kept at different duration. Witthayasan Kasetsat Witthayasat 41:282287.

Bach, S. J., T. A. McAllister, J. Baah, L. J. Yanke, D. M. Veira, V. P J. Gannon, and R. A. Holley. 2002. Persistence of Escherichia coli O157:H7 in barley silage: effect of a bacterial inoculant. J. Appl. Microbiol. 93:288-294.

Barnhart, S. K., and G. A. Dewell. 2011. Prussic Acid Poisoning Potential in Frosted Forages. Integrated Crop Management News. Paper 304. Accessed May 6, 2017. http://lib.dr.iastate.edu/ cropnews $/ 304$.

Becerra-Jiminez, J., M. Kuschak, E. Roeder, and H. Wiedenfeld. 2013. Toxic pyrrolizidine alkaloids as undesired contaminants in food and feed: Degradation of the PAs from Senecio jacobaea in silage. Pharmazie 68:636-639.

Bennett, S. D., K. A. Walsh, and L. H. Gould. 2013. Foodborne disease outbreaks caused by Bacillus cereus, Clostridium perfringens, and Staphylococcus aureus - United States, 1998-2008. Clin. Infect. Dis. 57:425-433.

Bennetts, H. W., E. J. Underwood, and F. L. Shier. 1946. A specific breeding problem of sheep on subterranean clover pastures in Western Australia. Aust. Vet. J. 22:2-12.

Berendonk, C., D. Cerff, K. Hünting, H. Wiedenfeld, J. Becerra, and M. Kuschak. 2010. Pyrrolizidine alkaloid level in Senecio jacobaea 
and Senecio erraticus-the effect of plant organ and forage conservation. Pages 669-671 in Proc. 23rd Gen. Meet Eur. Grassld Fed. Grassland in a Changing World, Kiel, Germany, vol. 15.

Beyer, J., O. H. Drummer, and H. H. Maurer. 2009. Analysis of toxic alkaloids in body samples. Forensic Sci. Int. 185:1-9.

Biesta-Peters, E. G., M. W. Reij, H. Joosten, L. G. M. Gorris, and M. H. Zwietering. 2010. Comparison of two optical-density-based methods and a plate count method for estimation of growth parameters of Bacillus cereus. Appl. Environ. Microbiol. 76:1399-1405.

Binev, R., I. Valchev, and J. Nikolov. 2006. Clinical and pathological studies on intoxication in horses from freshly cut Jimson weed (Datura stramonium)-contaminated maize intended for ensiling: clinical communication. J. S. Afr. Vet. Assoc. 77:215-219.

Binta, M. G., and E. Z. Mushi. 2012. Environmental factors associated with nitrate poisoning in livestock. J. Phylogenetics Evol. Biol. 3:131. https://doi.org/10.4172/2157-7463.1000131.

Blaney, B. J., R. A. McKenzie, J. R. Walters, L. F. Taylor, W. S Bewg, M. J. Ryley, and R. Maryam. 2000. Sorghum ergot (Claviceps africana) associated with agalactia and feed refusal in pigs and dairy cattle. Aust. Vet. J. 78:102-107.

Blaney, B. J., M. J. Ryley, and B. D. Boucher. 2010. Early harvest and ensilage of forage sorghum infected with ergot (Claviceps africana) reduces the risk of livestock poisoning. Aust. Vet. J. 88:311-312.

Bolan, N. S., and P. D. Kemp. 2003. A review of factors affecting and prevention of pasture-induced nitrate toxicity in grazing animals. Proc. N. Z. Grassl. Assoc. 65:171-178.

Bourry, A., B. Poutrel, and J. Rocourt. 1995. Bovine mastitis caused by Listeria monocytogenes: characteristics of natural and experimental infections. J. Med. Microbiol. 43:125-132.

Branca, F., and S. Lorenzetti. 2005. Health effects of phytoestrogens. Pages 100-111 in Diet Diversification and Health Promotion. Karger Publishers, Basel, Switzerland.

Brett, M. M., J. McLauchlin, A. Harris, S. O'Brien, N. Black, R. J Forsyth, D. Roberts, and F. J. Bolton. 2005. A case of infant botulism with a possible link to infant formula milk powder: evidence for the presence of more than one strain of Clostridium botulinum in clinical specimens and food. J. Med. Microbiol. 54:769-776.

Briese, R. R., and J. F. Couch. 1940. Hydrocyanic acid in sorghum silage. Vet. Med. 35:86-88.

Browne, N., and B. C. Dowds. 2002. Acid stress in the food pathogen Bacillus cereus. J. Appl. Microbiol. 92:404-414

Brvar, M., T. Ploj, G. Kozelj, M. Mozina, M. Noc, and M. Bunc. 2004. Case report: Fatal poisoning with Colchicum autumnale. Crit. Care 8:R56

Byrne, C. M., P. O'Kiely, D. J. Bolton, J. J. Sheridan, D. A. McDowell, and I. S. Blair. 2002. Fate of Escherichia coli O157:H7 during silage fermentation. J. Food Prot. 65:1854-1860.

Callaway, T. R., T. S. Edrington, A. D. Brabban, J. E. Keen, R. C. Anderson, M. L. Rossman, M. J. Engler, K. J. Genovese, B. L. Gwartney, J. O. Reagan, T. L. Poole, R. B. Harvey, E. M. Kutter, and D. J. Nisbet. 2006. Fecal prevalence of Escherichia coli O157, Salmonella, Listeria, and bacteriophage infecting E. coli O157:H7 in feedlot cattle in the southern plains region of the United States. Foodborne Pathog. Dis. 3:234-244.

Candrian, U., J. Lüthy, P. Schmid, Ch. Schlatter, and E. Gallasz. 1984. Stability of pyrrolizidine alkaloids in hay and silage. J. Agric. Food Chem. 32:935-937.

Carter, A. T., and M. W. Peck. 2015. Genomes, neurotoxins and biology of Clostridium botulinum Group I and Group II. Res. Microbiol. 166:303-317.

CAST. 2003. Mycotoxins: Risks in plant, animal, and human systems Task Force Report No. 139. Council for Agricultural Science and Technology, Ames, IA.

Chang, S. S., M. L. Wu, J. F. Deng, C. C. Lee, T. F. Chin, and S. J. Liao. 1999. Poisoning by Datura leaves used as edible wild vegetables. Vet. Hum. Toxicol. 41:242-245.

Cheeke, P. R. 1988. Toxicity and metabolism of pyrrolizidine alkaloids. J. Anim. Sci. 66:2343-2350.

Chen, X. Z., F. Feng, Q. H. Liu, and J. G. Zhang. 2014. Degrading mimosine and tannins of Leucaena leucocephala by ensiling. Appl. Mech. Mater. 618:349-353. (Trans Tech Publications)
Chen, Y., S. Sela, M. Gamburg, R. Pinto, and Z. G. Weinberg. 2005 Fate of Escherichia coli during ensiling of wheat and corn. Appl. Environ. Microbiol. 71:5163-5170.

Chizzola, R., G. Bassler, S. Winter, Q. Zebeli, and M. Kriechbaum. 2015. Persistence of alkaloids of typical poisonous plants autumn crocus and marsh ragwort in grass silage. Vet. Med. Austria 102:285-292.

Christiansson, A., J. Bertilsson, and B. Svensson. 1999. Bacillus cereus spores in raw milk: factors affecting the contamination of milk during the grazing period. J. Dairy Sci. 82:305-314.

Collins, M. D., and A. K. East. 1998. Phylogeny and taxonomy of the food-borne pathogen Clostridium botulinum and its neurotoxins. J. Appl. Microbiol. 84:5-17.

Collins-Thompson, D. L., and D. S. Woods. 1992. Control of C. botulinum in dairy products, Pages 261-278 in Clostridium botulinum: Ecology and Control in Foods. A. H. W. Hauschild and K. L. Dodds. ed. Marcel Dekker Inc., New York, NY.

Comis, D. 2000. The grass farmers love to hate. Agric. Res. 48:4-7.

Cortinovis, C., and F. Caloni. 2013. Epidemiology of intoxication of domestic animals by plants in Europe. Vet. J. 197:163-168.

Crawford, N. M. 1995. Nitrate: Nutrient and signal for plant growth. Plant Cell 7:859-868.

Crews, C. 2015. Analysis of ergot alkaloids. Toxins (Basel) 7:20242050.

Culvenor, C. C. J., J. A. Edgar, M. V. Jago, A. Outteridge, J. E. Peterson, and L. W. Smith. 1976. Hepato- and pneumotoxicity of pyrrolizidine alkaloids and derivatives in relation to molecular structure. Chem. Biol. Interact. 12:299-324.

Daems, F., V. Decruyenaere, R. Agneessens, G. Lognay, J. M. Romnee, and É. Froidmont. 2016. Changes in the isoflavone concentration in red clover (Trifolium pratense L.) during ensiling and storage in laboratory-scale silos. Anim. Feed Sci. Technol. 217:36-44.

Dagenais, T. R., and N. P. Keller. 2009. Pathogenesis of Aspergillus fumigatus in invasive aspergillosis. Clin. Microbiol. Rev. 22:447-465.

de Reu, K., K. Grijspeerdt, and L. Herman. 2004. A Belgian survey of hygiene indicator bacteria and pathogenic bacteria in raw milk and direct marketing of raw milk farm products. J. Food Saf. 24:17-36.

DeFrates, L. J., J. D. Hoehns, E. L. Sakornbut, D. G. Glascock, and A. R. Tew. 2005. Antimuscarinic intoxication resulting from the ingestion of moonflower seeds. Ann. Pharmacother. 39:173-176.

Desmasures, N., F. Bazin, and M. Guéguen. 1997. Microbiological composition of raw milk from selected farms in the Camembert region of Normandy. J. Appl. Microbiol. 83:53-58.

Dlabola, J., E. Hashish, B. Pauly, B. Kubisiak, I. Behm, R. Heseler, A. Schliephake, L. H. Wieler, H. Neubauer, and C. Seyboldt. 2016. Clostridium botulinum type D/C intoxication in a dairy cow stock in Saxony-Anhalt (Germany)-report on an innovative diagnostic approach. Berl. Munch. Tierarztl. Wochenschr. 129:111-117.

Donald, A. S., D. R. Fenlon, and B. Seddon. 1995. The relationships between ecophysiology, indigenous microflora and growth of Listeria monocytogenes in grass silage. J. Appl. Bacteriol. 79:141-148.

Doyle, C. J., D. Gleeson, K. Jordan, T. P. Beresford, R. P. Ross, G F. Fitzgerald, and P. D. Cotter. 2015. Anaerobic sporeformers and their significance with respect to milk and dairy products. Int. J. Food Microbiol. 197:77-87.

Driehuis, F. 2013. Silage and the safety and quality of dairy foods: A review. Agric. Food Sci. 22:16-34.

Dunière, L., A. Gleizal, F. Chaucheyras-Durand, I. Chevallier, and D. Thevenot-Sergentet. 2011. Fate of Escherichia coli O26 in corn silage experimentally contaminated at ensiling, at opening or after aerobic exposure and protective effect of various bacterial inoculants. Appl. Environ. Microbiol. 77:8696-8704.

EFSA (European Food Safety Authority). 2005. Opinion of the Scientific Panel on Biological Hazards on a request from the Commission related to Clostridium spp. in foodstuffs. EFSA J. 199:1-65.

EFSA (European Food Safety Authority) and ECDC (European Centre for Disease Prevention and Control). 2016. The European Union summary report on trends and sources of zoonoses, zoonotic agents and food-borne outbreaks in 2015. EFSA J. 14:4634-4865. 
Elrod, C. C., and W. R. Butler. 1993. Reduction in fertility and alteration of uterine $\mathrm{pH}$ in heifers fed excess ruminally degradable protein. J. Anim. Sci. 71:694-701.

Erdogan, H. M. 2010. Listerial keratoconjunctivitis and uveitis (silage eye). Vet. Clin. North Am. Food Anim. Pract. 26:505-510.

European Commission. 2005. Regulation (EC) No 2073/2005 on microbiological criteria for foodstuffs. European Commission, Brussels, Belgium.

European Commission. 2007. Regulation (EC) No 1441/2007 amending Regulation (EC) No 2073/2005 on microbiological criteria for foodstuffs. European Commission, Brussels, Belgium.

FAO. 2015. Strengthening control of bovine tuberculosis at the animalhuman-ecosystem interface. Food and Agriculture Organization of the United Nations. Accessed May 17, 2017. http://www.fao.org/ $\mathrm{ag} /$ againfo/programmes/en/empres/news_240315.html.

FAO and IDF. 2011. Guide to good dairy farming practice. Animal Production and Health Guidelines. No. 8. Food and Agriculture Organization of the United Nations and International Dairy Federation, Rome, Italy.

Fedio, W. M., M. Schoonderwoerd, R. H. Shute, and H. Jackson. 1990. A case of bovine mastitis caused by Listeria monocytogenes. Can. Vet. J. 31:773-775.

Fenlon, D. R. 1986. Growth of naturally occurring Listeria spp. in silage: A comparative study of laboratory and farm ensiled grass. Grass Forage Sci. 41:375-378.

Fenlon, D. R. 1988. Listeriosis. Pages $7-18$ in Silage and Health. B. A. Stark, and J. M. Wilkinson, ed. Chalcombe Publications, Marlow, UK.

Fenlon, D. R., and J. Wilson. 2000. Growth of Escherichia coli O157 in poorly fermented laboratory silage: a possible environmental dimension in the epidemiology of E. coli O157. Lett. Appl. Microbiol. 30:118-121.

Fenlon, D. R., J. Wilson, and J. R. Weddell. 1989. The relationship between spoilage and Listeria monocytogenes contamination in bagged and wrapped big bale silage. Grass Forage Sci. 44:97-100.

Fink-Gremmels, J. 2008. The role of mycotoxins in the health and performance of dairy cows. Vet. J. 176:84-92.

Flores-Flores, M. E., E. Lizarraga, A. López de Cerain, and E. González-Peñas. 2015. Presence of mycotoxins in animal milk: A review. Food Control 53:163-176.

Foyer, C. H., M.-H. Valadier, A. Migge, and T. W. Becker. 1998 Drought-induced effects on nitrate reductase activity and mRNA and on the coordination of nitrogen and carbon metabolism in maize leaves. Plant Physiol. 117:283-292.

Franzke, C. J., L. F. Puhr, and A. N. Hume. 1939. A study of sorghum with reference to the content of HCN. Accessed May 6, 2017. http://openprairie.sdstate.edu/cgi/viewcontent.cgi?article= 1013\&context=agexperimentsta_tb.

Fribourg, H. A., D. B. Hannaway, and C. P. West, eds. 2009. Tall Fescue for the Twenty-First Century. Agronomy Monographs 53. Am. Soc. Agron., Madison, WI.

Fu, P. P., Q. Xia, G. Lin, and M. W. Chou. 2004. Pyrrolizidine alkaloids - Genotoxicity, metabolism enzymes, metabolic activation, and mechanisms. Drug Metab. Rev. 36:1-55.

Galey, F. D., R. Terra, R. Walker, J. Adaska, M. A. Etchebarne, B. Puschner, E. Fisher, R. H. Whitlock, T. Rocke, D. Willoughby, and E. Tor. 2000. Type C botulism in dairy cattle from feed contaminated with a dead cat. J. Vet. Diagn. Invest. 12:204-209.

Gandhi, M., and M. L. Chikindas. 2007. Listeria: A foodborne pathogen that knows how to survive. Int. J. Food Microbiol. 113:1-15.

Gardini, F., Y. Ozoqui, G. Suzzi, G. Tabanelli, and F. Ozogui., 2016. Technological factors affecting biogenic amine content in food: A review. Front. Microbiol. 7:1218. https://doi.org/10.3389/fmicb .2016.01218.

Garnett, B. T., R. J. Delahay, and T. J. Roper. 2002. Use of cattle farm resources by badgers (Meles meles) and risk of bovine tuberculosis (Mycobacterium bovis) transmission. Proc. Biol. Sci. 269:1487-1491.

Gould, L. H., R. K. Mody, K. L. Ong, P. Clogher, A. B. Cronquist, K. N. Garman, S. Lathrop, C. Medus, N. L. Spina, T. H. Webb, P. L. White, K. Wymore, R. E. Gierke, B. E. Mahon, and P.
M. Griffin. 2013. Emerging Infections Program Foodnet Working Group. Increased recognition of non-O157 Shiga toxin-producing Escherichia coli infections in the United States during 2000-2010: Epidemiologic features and comparison with E. coli O157 infections. Foodborne Pathog. Dis. 10:453-460.

Gray, E., J. S. Rice, D. Wattenbarger, J. A. Benson, A. J. Hester, R. C. Loyd, and B. M. Greene. 1968. Hydrocyanic acid potential of sorghum plants grown in Tennessee. Bulletins. Accessed May 6 , 2017. http://trace.tennessee.edu/utk_agbulletin/156.

Gray, T. C., and M. S. Bulgin. 1982. Botulism in an Oregon dairy cow herd. J. Am. Vet. Med. Assoc. 180:160-162.

Grayson, R. R. 1956. Silage gas poisoning: Nitrogen dioxide pneumonia, a new disease in agricultural workers. Ann. Intern. Med. 45:393-408.

Griffiths, M. W. 1992. Bacillus cereus in liquid milk and other milk products. Pages 36-39 in Bulletin of the International Dairy Federation No. 275. International Dairy Federation, Brussels, Belgium.

Haagsma, J., and E. A. Ter Laak. 1978a. Atypical cases of type B botulism in cattle, caused by supplementary feeding of brewers' grains. Tijdschr. Diergeneeskd. 103:312-325.

Haagsma, J., and E. A. Ter Laak. 1978b. Type B botulism in cattle caused by feeding grass silage. Report of a case. Tijdschr. Diergeneeskd. 103:910-912.

Hammond, A. C. 1995. Leucaena toxicosis and its control in ruminants. J. Anim. Sci. 73:1487-1492.

Heyndrickx, M., and P. Scheldeman. 2002. Bacilli associated with spoilage in dairy and other food products. Pages 64-82 in Applications and Systematics of Bacillus and Relatives. R. Berkeley, M. Heyndrickx, N. Logan, and P. De Vos, ed. Blackwell Science, Oxford, UK

Ho, A. J., R. Ivanek, Y. T. Gröhn, K. K. Nightingale, and M. Wiedmann. 2007. Listeria monocytogenes fecal shedding in dairy cattle shows high levels of day-to-day variation and includes outbreaks and sporadic cases of shedding of specific L. monocytogenes subtypes. Prev. Vet. Med. 80:287-305.

Jones, R. J., C. G. Blunt, and J. H. G. Holmes. 1976. Enlarged thyroid glands in cattle grazing Leucaena pastures. Trop. Grassl. 10:113-116.

Jones, R. J., and M. P. Hegarty. 1984. The effect of different proportions of Leucaena leucocephala in the diet of cattle on growth, feed intake, thyroid function and urinary excretion of 3-hydroxy-4 (1H)-pyridone. Crop Pasture Sci. 35:317-325

Jordan, E. R., T. E. Chapman, D. W. Holtan, and L. V. Swanson. 1983. Relationship of dietary crude protein to composition of uterine secretions and blood in high-producing postpartum dairy cows. J. Dairy Sci. 66:1854-1862.

Kallah, M. S., M. Baba, J. P. Alawa, I. R. Muhammad, and R. J. Tanko. 1997. Ensiling quality of columbus grass (Sorghum almum) grown in northern Nigeria. Anim. Feed Sci. Technol. 68:153-163.

Kallela, K. 1975. The effect of storage on the estrogenic effect of red clover silage. Nord. Vet. Med. 27:562-569.

Kallela, K., K. Heininen, and H. Saloniemi. 1984. Plant oestrogens; the cause of decreased fertility in cows. A case report. Nord. Vet. Med. 36:124-129.

Karam, F. S. C., and A. Motta. 2011. Pyrrolizidine alkaloids poisoning in cattle in the state of Rio Grande do Sul, Brazil. Pages 175-178 in Poisoning by Plants, Mycotoxins and Related Toxins. F. RietCorra, ed. CAB International, Wallingford, UK.

Kauffman, A. J., and N. R. St-Pierre. 2001. The relationship of milk urea nitrogen to urine nitrogen excretion in Holstein and Jersey cows. J. Dairy Sci. 84:2284-2294.

Kavana, P. Y., and A. Kiddo Mtunda. Abass, and V. Rweyendera. 2005. Promotion of cassava leaves silage utilization for smallholder dairy production in Eastern coast of Tanzania. Livestock Research for Rural Development. Accessed May 10, 2017. https://www.researchgate.net/profile/Pius_Kavana/publication/ 207502198_Promotion_of_cassava_leaves_silage_utilization_for _smallholder_dairy_production_in_Eastern_coast_of_Tanzania/ links/54ccee570cf29ca810f73073.pdf.

Kelch, W. J., L. A. Kerr, J. K. Pringle, B. W. Rohrbach, and R. H. Whitlock. 2000. Fatal Clostridium botulinum toxicosis in eleven 
Holstein cattle fed round bale barley haylage. J. Vet. Diagn. Invest. 12:453-455.

Khorasani, G. R., P. E. Jedel, J. H. Helm, and J. J. Kennelly. 1997. Influence of stage of maturity on yield components and chemical composition of cereal grain silages. Can. J. Anim. Sci. 77:259-267.

Krízek, M. 1993. Biogenic amines in silage 1. The occurrence of biogenic amines in silage. Arch. Tierenahr. 43:169-177.

Krizek, M., P. Kalac, and J. Peterka. 1993. Biogenic amines in silage 3 . The occurrence of six biogenic amines in farm-scale grass and maize silages. Arch. Tierenahr. 45:131-137.

Kummel, J., R. Krametter-Froetscher, G. Six, R. Brunthaler, W Baumgartner, and B. Altenbrunner-Martinek. 2012. Descriptive study of botulism in an Austrian dairy herd: a case report. Vet. Med. (Praha) 57:143-149.

Kung, L., Jr., M. R. Stokes, and C. J. Lin. 2003. Silage additives, Pages 305-360 in Silage Science and Technology. D. R. Buxton, R. E. Muck, and J. H. Harrison, ed. Am. Soc. Agron., Madison, WI.

Kupper, J., K. Rentsch, A. Mittelholzer, R. Artho, S. Meyer, H. Kupferschmidt, and H. Naegeli. 2010. A fatal case of autumn crocus (Colchicum autumnale) poisoning in a heifer: Confirmation by mass-spectrometric colchicine detection. J. Vet. Diagn. Invest. 22:119-122.

Ladero, V., M. Calles-Enriquez, M. Fernandez, and M. A. Alvarez. 2010. Toxicological effects of dietary biogenic amines. Curr. Nutr. Food Sci. 6:145-156.

Lawlor, D. W., F. A. Boyle, A. J. Keys, A. C. Kendall, and A. T. Young. 1988. Nitrate nutrition and temperature effects on wheat: A synthesis of plant growth and nitrogen uptake in relation to metabolic and physiological processes. J. Exp. Bot. 39:329-343.

Lean, I. J. 2001. Association between feeding perennial ryegrass ( $\mathrm{Lo}-$ lium perenne cultivar Grasslands Impact) containing high concentrations of ergovaline, and health and productivity in a herd of lactating dairy cows. Aust. Vet. J. 79:262-264.

Lee, C., and K. A. Beauchemin. 2014. A review of feeding supplementary nitrate to ruminant animals: Nitrate toxicity, methane emission and production performance. Can. J. Anim. Sci. 94:54575570 .

Leibensperger, R. Y., and R. E. Pitt. 1987. A model of clostridial dominance in ensilage. Grass Forage Sci. 42:297-317.

Linares, D. M., M. C. Martin, V. Ladero, M. A. Alvarez, and M. Fernández. 2011. Biogenic amines in dairy products. Crit. Rev. Food Sci. Nutr. 51:691-703.

Lindström, M., J. Myllykoski, S. Sivelä, and H. Korkeala. 2010. Clostridium botulinum in cattle and dairy products. Crit. Rev. Food Sci. Nutr. 50:281-304.

Lingaas, F., and B. Tveit. 1992. Etiology of acetonemia in Norwegian cattle. 2. Effect of butyric acid, valeric acid and putrescine. J. Dairy Sci. 75:2433-2439.

Lira, W. M., C. Macedo, and J. M. Marin. 2004. The incidence of Shiga toxin-producing Escherichia coli in cattle with mastitis in Brazil. J. Appl. Microbiol. 97:861-866.

Lomonaco, S., D. Nucera, and V. Filipello. 2015. The evolution and epidemiology of Listeria monocytogenes in Europe and the United States. Infect. Genet. Evol. 35:172-183.

Lookhart, G. L. 1980. Analysis of coumestrol, a plant estrogen, in animal feeds by high-performance liquid chromatography. J. Agric. Food Chem. 28:666-667.

Lounglawan, P., M. Khungaew, and W. Suksombat. 2011. Silage production from cassava peel and cassava pulp as energy source in cattle diets. J. Anim. Vet. Adv. 10:1007-1011.

Magnusson, M., A. Christiansson, and B. Svensson. 2007. Bacillus cereus spores during housing of dairy cows: Factors affecting contamination of raw milk. J. Dairy Sci. 90:2745-2754.

Magnusson, M., A. Christiansson, B. Svensson, and C. Kolstrup. 2006. Effect of different premilking manual teat-cleaning methods on bacterial spores in milk. J. Dairy Sci. 89:3866-3875.

Majowicz, S. E., E. Scallan, A. Jones-Bitton, J. M. Sargeant, J. Stapleton, F. J. Angulo, D. H. Yeung, and M. D. Kirk. 2014. Global incidence of human Shiga toxin-producing Escherichia coli infections and deaths: a systematic review and knowledge synthesis. Foodborne Pathog. Dis. 11:447-455.
Marshall, J. C., T. K. Soboleva, P. Jamieson, and N. P. French. 2016 Estimating bacterial pathogen levels in New Zealand bulk tank milk. J. Food Prot. 79:771-780.

Martin, A. K., and K. L. Blaxter. 1965. The energy cost of urea synthesis in sheep. Pages 83-91 in Energy Metabolism. K. L. Blaxter, ed. Academic Press, New York, NY.

Mattocks, A. R. 1968. Toxicity of pyrrolizidine alkaloids. Nature 217:723-728.

Mattocks, A. R. 1986. Chemistry and Toxicology of Pyrrolizidine Alkaloids. Academic Press, New York, NY.

McCarty, G., E. Gray, E. R. Shipe, and L. D. Brown. 1971. Effects of ensiling on the hydrocyanic acid potential of sorghum plants. Agron. J. 63:402-403.

McDonald, P., A. R. Henderson, and S. J. E. Heron. 1991 The Biochemistry of Silage. 2nd ed. Chalcombe Publications, Marlow, UK

McLean, E. K. 1970. The toxic actions of pyrrolizidine (Senecio) alkaloids. Pharmacol. Rev. 22:429-483.

Mikołajczak, J., L. Podkówka, Z. Podkówka, and E. Staszak. 2005. Effects of endophyte infection of grasses on the chemical composition, quality and stability of silage. Folia Biol. (Krakow) 53:67-72.

Miller, F. A., and J. A. Stroup. 2004. Growth and management or sorghums for forage production. National Alfalfa Symposium. Monterey, CA. Accessed May 10, 2017. http://alfalfa.ucdavis.edu/ +symposium/proceedings/2004/04-149.pdf.

Miller, R. A., D. J. Kent, M. J. Watterson, K. J. Boor, N. H. Martin, and M. Wiedmann. 2015. Spore populations among bulk tank raw milk and dairy powders are significantly different. J. Dairy Sci 98:8492-8504

Molloy, J. B., C. J. Moore, A. G. Bruyeres, S. A. Murray, and B. J Blaney. 2003. Determination of dihydroergosine in sorghum ergot using an immunoassay. J. Agric. Food Chem. 51:3916-3919.

Molyneux, R. J., A. E. Johnson, J. D. Olsen, and D. C. Baker. 1991. Toxicity of pyrrolizidine alkaloids from Riddell groundsel (Senecio riddellii) to cattle. Am. J. Vet. Res. 52:146-151.

Moravcová, J., T. Kleinová, R. Loucka, I. Tyrolová, F. Kvasnicka, M. Dusek, and M. Cerovsky. 2003. Effect of additives on coumestrol content in laboratory alfalfa silages. Czech J. Anim. Sci. 48:425431.

Moravcová, J., T. Kleinová, R. Loučka, I. Tyrolová, F. Kvasnička, M. Dušek, M. Čeřovský, and P. Matucha. 2004. Coumestrol content of alfalfa following ensilage. Anim. Feed Sci. Technol. 115:159-167.

Mostrom, M. S., and B. J. Jacobsen. 2011. Ruminant mycotoxicosis. Vet. Clin. North Am. Food Anim. Pract. 27:315-344.

Muck, R. E., L. E. Moser, and R. E. Pitt. 2003. Postharvest factors affecting ensiling. Pages 251-304 in Silage Science and Technology. D. R. Buxton, R. E. Muck, and J. H. Harrison, ed. Am. Soc. Agron., Madison, WI.

Muck, R. E., E. M. G. Nadeau, T. A. McAllister, F. E. ContrerasGovea, M. C. Santos, and L. Kung Jr. 2018. Silage review: Recent advances and future uses of silage additives. J. Dairy Sci. 101:3980-4000. https://doi.org/10.3168/jds.2017-13739.

Murkies, A. L., G. Wilcox, and S. R. Davis. 1998. Phytoestrogens. J. Clin. Endocrinol. Metab. 83:297-303.

Myllykoski, J., M. Lindström, R. Keto-Timonen, H. Söderholm, J. Jakala, H. Kallio, A. Sukura, and H. Korkeala. 2009. Type C bovine botulism outbreak due to carcass contaminated non-acidified silage. Epidemiol. Infect. 137:284-293.

Naudè, T. W., C. J. Botha, J. H. Vorster, C. Roux, E. J. Van der Linde, S. I. Van der Walt, G. E. Rottinghaus, L. Van Jaarsveld, and A. N. Lawrence. 2005. Claviceps cyperi, a new cause of severe ergotism in dairy cattle consuming maize silage and teff hay contaminated with ergotised Cyperus esculentus (nut sedge) on the Highveld of South Africa. Onderstepoort J. Vet. Res. 72:23-37.

Ngwa, T. A., I. V. Nsahlai, and P. A. Iji. 2004. Ensilage as a means of reducing the concentration of cyanogenic glycosides in the pods of Acacia sieberiana and the effect of additives on silage quality. J. Sci. Food Agric. 84:521-529.

Nightingale, K. K., Y. H. Schukken, C. R. Nightingale, E. D. Fortes, A. J. Ho, Z. Her, Y. T. Gröhn, P. L. McDonough, and M. Wiedmann. 2004. Ecology and transmission of Listeria monocytogenes 
infecting ruminants and in the farm environment. Appl. Environ. Microbiol. 70:4458-4467.

Nishino, N., H. Hattori, H. Wada, and E. Touno. 2007. Biogenic amine production in grass, maize and total mixed ration silages inoculated with Lactobacillus casei or Lactobacillus buchneri. J. Appl. Microbiol. 103:325-332.

Notermans, S., J. Dufrenne, and J. Oosterom. 1981. Persistence of Clostridium botulinum type B on a cattle farm after an outbreak of botulism. Appl. Environ. Microbiol. 41:179-183.

O'Hagan, D. 2000. Pyrrole, pyrrolidine, pyridine, piperidine and tropane alkaloids. Nat. Prod. Rep. 17:435-446.

O'Kiely, P., T. Turley, and P. A. M. Rogers. 1999. Exposure of calves to nitrogen dioxide in silage gas. Vet. Rec. 144:352-353.

Oetzel, G. R. 2007. Herd-level ketosis-Diagnosis and risk factors. Proc. 40th Ann. Conf. Amer. Assoc. Bovine Pract., Preconf. Sem. 7C, Accessed Nov. 8, 2016. https://www.vetmed.wisc.edu/dms/ fapm/fapmtools/2nutr/ketosis.pdf.

Ogunade, I. M., Y. Jiang, D. H. Kim, A. A. Pech Cervantes, K. G. Arriola, D. Vyas, Z. G. Weinberg, K. C. Jeong, and A. T. Adesogan. 2017. Fate of Escherichia coli O157:H7 and bacterial diversity in corn silage contaminated with the pathogen and treated with chemical or microbial additives. J. Dairy Sci. 100:1780-1794.

Ogunade, I. M., Y. Jiang, C. Martinez Tuppia, O. C. M. Queiroz, P. Drouin, and A. T. Adesogan. 2018. Silage review: Mycotoxins in silage: Occurrence, effects, prevention, and mitigation. J. Dairy Sci. 101:4034-4059. https://doi.org/10.3168/jds.2017-13788.

Ogunade, I. M., D. H. Kim, Y. Jiang, Z. G. Weinberg, K. C. Jeong, and A. T. Adesogan. 2016. Control of Escherichia coli O157:H7 in contaminated alfalfa silage: Effects of silage additives. J. Dairy Sci. 99:4427-4436.

Pace, V., K. Carbone, F. Spirito, M. Iacurto, M. G. Terzano, M. Verna, F. Vincenti, and D. Settineri. 2006. The effects of subterranean clover phytoestrogens on sheep growth, reproduction and carcass characteristics. Meat Sci. 74:616-622.

Pahlow, G., R. E. Muck, F. Driehuis, S. J. W. H. Oude-Elfereink, and S. F. Spoelstra. 2003. Microbiology of ensiling. Pages 31-93 in Silage Science and Technology. D. R. Buxton, R. E. Muck, and J. H. Harrison, ed. Am. Soc. Agron., Madison, WI.

Panaccione, D. G., R. D. Johnson, J. Wang, C. A. Young, P. Damrongkool, B. Scott, and C. L. Schardl. 2001. Elimination of ergovaline from a grass-Neotyphodium endophyte symbiosis by genetic modification of the endophyte. Proc. Natl. Acad. Sci. USA $98: 12820-12825$.

Payne, J. H., R. A. Hogg, A. Otter, H. I. Roest, and C. T. Livesey. 2011. Emergence of suspected type D botulism in ruminants in England and Wales (2001 to 2009), associated with exposure to broiler litter. Vet. Rec. 168:640.

Pedroso, A. F., A. T. Adesogan, O. C. M. Queiroz, and S. K. Williams. 2010. Control of Escherichia coli O157:H7 in corn silage with or without various inoculants: Efficacy and mode of action. J. Dairy Sci. 93:1098-1104.

Pelhate, J. 1977. Maize silage: Incidence of moulds during conservation. Folia Vet. Lat. 7:1-16.

Phesatcha, K., and M. Wanapat. 2015. Improvement of Leucaena silage nutritive value and in vitro ruminal fermentation by molasses and urea supplementation. Asian-australas. J. Anim. Sci. 29:11361144. https://doi.org/10.5713/ajas.15.0591.

Phillips, C. J. C. 2005. The epidemiology and control of bovine tuberculosis. Pages 203-247 in Focus on Tuberculosis Research. L. T. Smithe, ed. Nova Biomedical Books, New York, NY.

Phuntsok, T., M. A. Froetschel, H. E. Amos, and Y. W. Huang. 1998. Biogenic amines in silage, apparent postruminal passage, and the relationship between biogenic amines and digestive function and intake by steers. J. Dairy Sci. 81:2193-2203.

Pinho, E. Z. D., C. Costa, M. D. B. Arrigoni, A. C. Silveira, C. R. Padovani, and S. Z. D. Pinho. 2004. Fermentation and nutritive value of silage and hay made from the aerial part of cassava (Manihot esculenta Crantz). Sci. Agric. 61:364-370.

Prakash, A. S., T. N. Pereira, P. E. Reilly, and A. A. Seawright. 1999. Pyrrolizidine alkaloids in human diet. Mutat. Res. 443:53-67.
Puntenney, S. B., Y. Wang, and N. E. Forsberg. 2002. Keeping them out of the rough: Practical Insights into Hemorrhagic Bowel Syndrome. J. Am. Vet. Med. Assoc. 331:686-689.

Rao, M., T. L. Struer, F. E. Aldwell, and G. M. Cook. 2001. Intracellular $\mathrm{pH}$ regulation by Mycobacterium smegmatis and Mycobacterium bovis BCG. Microbiology 147:1017-1024.

Rasby, R. J., B. E. Anderson, and P. J. Kononoff. 2014. Nitrates in livestock feeding. University of Nebraska-Lincoln Extension, Inst. Agric. Nat. Res., Beef Feeding and Nutrition G1779. Nebraska Extension, University of Nebraska, Lincoln.

Roberts, C., R. Kallenbach, and N. Hill. 2002. Harvest and storage method affects ergot alkaloid concentration in tall fescue. Crop Manag. https://doi.org/10.1094/CM-2002-0917-01-BR.

Roberts, C. A., D. K. Davis, M. L. Looper, R. L. Kallenbach, G. E. Rottinghaus, and N. S. Hill. 2014. Ergot alkaloid concentrations in high-and low-moisture tall fescue silage. Crop Sci. 54:1887-1892.

Roberts, C. A., R. L. Kallenbach, G. E. Rottinghaus, and N. S. Hill. 2011. Ergovaline and ergot alkaloid concentrations change in conserved tall fescue. Forage Grazinglands 9. https://doi.org/10 .1094/FG-2011-1013-01-RS.

Rogerie, F., A. Marecata, S. Gambade, F. Dupond, P. Beaubois, and M. Lange. 2001. Characterization of Shiga toxin producing $E$. coli and O157 serotype E. coli isolated in France from healthy domestic cattle. Int. J. Food Microbiol. 63:217-223.

Rooke, J. A., and R. D. Hatfield. 2003. Biochemistry of ensiling. Pages 95-139 in Silage Science and Technology. D. R. Buxton, R. E. Muck, and J. H. Harrison, ed. Am. Soc. Agron., Madison, WI.

Ryser, E. T., S. M. Arimi, and C. W. Donnelly. 1997. Effects of pH on distribution of Listeria ribotypes in corn, hay, and grass silage. Appl. Environ. Microbiol. 63:3695-3697.

Sanaa, M., B. Poutrel, J. L. Menard, and F. Serieys. 1993. Risk factors associated with contamination of raw milk by Listeria monocytogenes in dairy farms. J. Dairy Sci. 76:2891-2898.

Sarelli, L., M. Tuori, I. Saastamoinen, L. Syrjälä-qvist, and H. Saloniemi. 2003. Phytoestrogen content of birdsfoot trefoil and red clover: Effects of growth stage and ensiling method. Acta Agric. Scand. A 53:58-63.

Sarfati, J., H. E. Jensen, and J. P. Latgé. 1996. Route of infections in bovine aspergillosis. J. Med. Vet. Mycol. 34:379-383.

Scallan, E., R. M. Hoekstra, F. J. Angulo, R. V. Tauxe, M. A. Widdowson, S. L. Roy, J. L. Jones, and P. M. Griffin. 2011. Foodborne illness acquired in the United States-Major pathogens. Emerg. Infect. Dis. 17:7-15.

Schantz, E. J., and E. A. Johnson. 1992. Properties and use of botulinum toxin and other microbial neurotoxins in medicine. Microbiol. Rev. 56:80-99.

Schatzmayr, G., and E. Streit. 2013. Global occurrence of mycotoxins in the food and feed chain: facts and figures. World Mycotoxin J. 6:213-222.

Scherer, R., K. Gerlach, and K.-H. Sudukum. 2015. Biogenic amines and gamma amino butyric acid in sialges: Formation, occurrence and influence on dry matter intake and ruminant production. Anim. Feed Sci. Technol. 210:1-16.

Schneider, D. J., C. O. Miles, I. Garthwaite, A. Van Halderen, J. C. Wessels, and H. J. Lategan. 1996. First report of field outbreaks of ergot-alkaloid toxicity in South Africa. Onderstepoort J. Vet. Res. 63:97-108.

Seaman, J. T. 1987. Pyrrolizidine alkaloid poisoning of sheep in New South Wales. Aust. Vet. J. 64:164-167.

Seaman, J. T., and K. H. Walker. 1985. Pyrrolizidine alkaloid poisoning of cattle and horses in New South Wales. In Plant toxicology. Pages 235-246 in Proceedings of the Australia-USA poisonous plants symposium, Brisbane, Australia. Animal Research Institute, Yeerongpilly, QLD, Australia.

Shelton, H. M., and J. L. Brewbaker. 1998. 2.1 Leucaena leucocepha$l a$-The most widely used forage tree legume. Forage tree legumes in tropical agriculture. St Lucia, Queensland: Tropical Grassland Society of Australia Inc. Accessed May 16, 2017. https:// www.doc-developpement-durable.org/file/Arbres-Bois-de-Rapport -Reforestation/FICHES_ARBRES/bonaramantsina\%20Leucaena \%20leucocephala/Leucaena\%20leucocephala\%20(1).pdf. 
Sivesind, E., and P. Seguin. 2005. Effects of the environment, cultivar, maturity, and preservation method on red clover isoflavone concentration. J. Agric. Food Chem. 53:6397-6402.

Smith, D. F., and G. P. Lynch. 1973. Aspergillus fumigatus in samples of moldy silage. J. Dairy Sci. 56:828-829.

Sobel, J., N. Tucker, A. Sulka, J. McLaughlin, and S. Maslanka. 2004. Foodborne botulism in the United States, 1990-2000. Emerg. Infect. Dis. 10:1606-1611.

Soler-Rodríguez, F., A. Martín, J. P. García-Cambero, A. L. Oropesa and M. Pérez-López. 2006. Datura stramonium poisoning in horses: A risk factor for colic. Vet. Rec. 158:132-133.

Spoelstra, S. F. 1983. Inhibition of clostridial growth by nitrate during the early phase of silage fermentation. J. Sci. Food Agric. $34: 145-152$.

Srinivasulu, C., M. R. L. Prabhu, and B. C. Devi. 2000. Influence of ensiling on mimosine content of subabul (Leucaena leucocephala). JNKVV Research Journal 34:67-69.

Steidlová, S., and P. Kalac. 2004. The effects of lactic acid bacteria inoculants and formic acid on the formation of biogenic amines in grass silages. Arch. Anim. Nutr. 58:245-254.

Steyn, D. G. 1933. Poisoning of human beings by weeds contained in cereals (bread poisoning). Onderstepoort J. Vet. Sci. Anim. Ind. 1:219-266.

Sunagawa, K., F. Hongo, Y. Kawashima, and S. Tawata. 1989. The effect of mimosine reduced Leucaena feed on sheep. Jpn. J. Zootech. Sci. 60:133-140.

Tasci, F., H. Turutoglu, and H. Ogutcu. 2010. Investigations of Listeria species in milk and silage produced in Burdur province. Kafkas Univ. Vet. Fak. Derg. 16(Suppl. A):S93-S97.

Te Giffel, M. C. 1997. Isolation, identification and characterization of Bacillus cereus from the dairy environment. PhD thesis. Agricultural University Wageningen, the Netherlands.

TePaske, M. R., R. G. Powell, and S. L. Clement. 1993. Analyses of selected endophyte-infected grasses for the presence of loline-type and ergot-type alkaloids. J. Agric. Food Chem. 41:2299-2303.

Toaima, S. A., M. M. Lamlom, T. I. Abdel-Wahab, and S. I. AbdelWahab. 2014. Allelopathic effects of sorghum and Sudan grass on some following winter field crops. Int. J. Plant Soil Sci. 3:599-622.

Turner, K. E., C. P. West, E. L. Piper, S. A. Mashburn, and A. S. Moubarak. 1993. Quality and ergovaline content of tall fescue silage as affected by harvest stage and addition of poultry litter and inoculum. J. Prod. Agric. 6:423-427.

Ty, C., J. Ly, and L. Rodríguez. 2001. An approach to ensiling conditions for preservation of cassava foliage in Cambodia. Livestock Research for Rural Development. Accessed May 10, 2017. http:/ www.lrrd.cipav.org.co/lrrd13/2/chha132.htm.

Unnerstad, H., A. Romell, H. Ericsson, M. L. Danielsson-Tham, and W. Tham. 2000. Listeria monocytogenes in faeces from clinically healthy dairy cows in Sweden. Acta Vet. Scand. 41:167-171.

Van der Veen, S., R. Moezelaar, T. Abee, and M. H. J. Wells-Bennik. 2008. The growth limits of a large number of Listeria monocyto- genes strains at combinations of stresses show serotype- and nichespecific traits. J. Appl. Microbiol. 105:1246-1258.

Van Kessel, J. A. S., J. S. Karns, J. E. Lombard, and C. A. Kopral. 2011. Prevalence of Salmonella enterica, Listeria monocytogenes, and Escherichia coli virulence factors in bulk tank milk and in-line filters from U.S. dairies. J. Food Prot. 74:759-768.

Van Os, M., B. Lassalas, S. Toillon, and J. P. Jouany. 1995. In vitro degradation of amines by rumen microorganisms. J. Agric. Sci. 125:299-305.

Van Os, M., A. M. Van Vuuren, and S. F. Spoelstra. 1997. Mechanisms of adaption in sheep to overcome silage intake depression induced by biogenic amines. Br. J. Nutr. 77:399-415.

Van Os, M., P. G. Van Wikselaar, and S. F. Spoelstra. 1996. Formation of biogenic amines in well fermented grass silages. J. Agric. Sci. 127:97-107.

Vilar, M. J., E. Yus, M. L. Sanjuán, J. L. Diéguez, and F. J. Rodríguez-Otero. 2007. Prevalence of and risk factors for Listeria species on dairy farms. J. Dairy Sci. 90:5083-5088.

Vissers, M. M. M., F. Driehuis, M. C. Te Giffel, P. De Jong, and J. M. G. Lankveld. 2007a. Quantification of the transmission of microorganisms to milk via dirt attached to the exterior of teats. J. Dairy Sci. 90:3579-3582.

Vissers, M. M. M., F. Driehuis, M. C. Te Giffel, P. De Jong, and J. M. G. Lankveld. 2007b. Minimizing the level of Bacillus cereus spores in farm tank milk. J. Dairy Sci. 90:3286-3293.

Vough, L. R., and E. K. Cassel. 2006. Prussic Acid Poisoning of Livestock: Causes and Prevention. 2006. Accessed May 6, 2017. http://openprairie.sdstate.edu/cgi/viewcontent.cgi? article $=1114$ \&context=extension_extra.

Weinberg, Z. G., R. E. Muck, and P. J. Weimer. 2003. The survival of silage inoculant lactic acid bacteria in rumen fluid. J. Appl. Microbiol. 94:1066-1071.

Weiss, W. P., D. G. Chamberlain, and C. W. Hunt. 2003. Feeding silages. Pages 469-504 in Silage Science and Technology. D. R. Buxton, R. E. Muck, and J. H. Harrison, ed. Am. Soc. Agron., Madison, WI.

Wiedmann, M., T. Arvik, J. L. Bruce, J. Neubauer, F. del Piero, and M. C. Smith. 1997. Investigation of a listeriosis epizootic in sheep in New York state. Am. J. Vet. Res. 58:733-737.

Willmott, F. C., and G. W. Robertson. 1920. Senecio disease or cirrhosis of the liver due to Senecio poisoning. Lancet 196:848-849.

World Health Organization and FAO. 2009. Guidelines on the Application of general principles of Food Hygiene to the Control of Listeria monocytogenes. Codex Alimentarius, International Food Standards CAC/GL 61 - 2007. FAO, Rome, Italy.

Yamada, M., M. Nakagawa, M. Haritani, M. Kobayashi, H. Furuoka, and T. Matsui. 1998. Histopathological study of experimental acute poisoning of cattle by autumn crocus. (Colchicum autumnale L). J. Vet. Med. Sci. 60:949-952. 